\title{
Source-sector contributions to European ozone and fine PM in 2010 using AQMEII modeling data
}

\author{
Prakash Karamchandani $^{1}$, Yoann Long ${ }^{2}$, Guido Pirovano $^{3}$, Alessandra Balzarini ${ }^{3}$, and Greg Yarwood ${ }^{1}$ \\ ${ }^{1}$ Ramboll Environ, Inc., 773 San Marin Drive, Suite 2115, Novato, CA 94998, USA \\ ${ }^{2}$ Ramboll Environ, Inc., Immeuble Le Cézanne, 155 rue de Broglie, 13100 Aix-en-Provence, France \\ ${ }^{3}$ Ricerca sul Sistema Energetico (RSE SpA), Via Rubattino, 54 - 20134 Milan, Italy \\ Correspondence to: Prakash Karamchandani (pkaramchandani@ramboll.com)
}

Received: 3 November 2016 - Discussion started: 11 November 2016

Revised: 24 March 2017 - Accepted: 30 March 2017 - Published: 4 May 2017

\begin{abstract}
Source apportionment modeling provides valuable information on the contributions of different source sectors and/or source regions to ozone $\left(\mathrm{O}_{3}\right)$ or fine particulate matter $\left(\mathrm{PM}_{2.5}\right)$ concentrations. This information can be useful in designing air quality management strategies and in understanding the potential benefits of reducing emissions from a particular source category. The Comprehensive Air quality Model with Extensions (CAMx) offers unique source attribution tools, called the Ozone and Particulate Source Apportionment Technology (OSAT/PSAT), which track source contributions. We present results from a CAMx source attribution modeling study for a summer month and a winter month using a recently evaluated European CAMx modeling database developed for Phase 3 of the Air Quality Model Evaluation International Initiative (AQMEII). The contributions of several source sectors (including model boundary conditions of chemical species representing transport of emissions from outside the modeling domain as well as initial conditions of these species) to $\mathrm{O}_{3}$ or $\mathrm{PM}_{2.5}$ concentrations in Europe were calculated using OSAT and PSAT, respectively. A 1-week spin-up period was used to reduce the influence of initial conditions. Evaluation focused on 16 major cities and on identifying source sectors that contributed above $5 \%$. Boundary conditions have a large impact on summer and winter ozone in Europe and on summer $\mathrm{PM}_{2.5}$, but they are only a minor contributor to winter $\mathrm{PM}_{2.5}$. Biogenic emissions are important for summer ozone and $\mathrm{PM}_{2.5}$. The important anthropogenic sectors for summer ozone are transportation (both on-road and non-road), energy production and conversion, and industry. In two of the 16 cities, solvent and product also contributed above $5 \%$ to summertime ozone. For summer-
\end{abstract}

time $\mathrm{PM}_{2.5}$, the important anthropogenic source sectors are energy, transportation, industry, and agriculture. Residential wood combustion is an important anthropogenic sector in winter for $\mathrm{PM}_{2.5}$ over most of Europe, with larger contributions in central and eastern Europe and the Nordic cities. Other anthropogenic sectors with large contributions to wintertime $\mathrm{PM}_{2.5}$ include energy, transportation, and agriculture.

\section{Introduction}

Photochemical grid models (PGMs), such as the Comprehensive Air quality Model with Extensions (CAMx; Ramboll Environ, 2014) and the Community Multiscale Air Quality (CMAQ) model (Byun and Schere, 2006), are widely used in air quality management to assess the effectiveness of potential control strategies for secondary pollutants such as $\mathrm{O}_{3}$ and fine particulate matter $\left(\mathrm{PM}_{2.5}\right)$. Source apportionment (SA) analysis is an important component of this process to identify source sectors and/or regions that are contributing to $\mathrm{O}_{3}$ and $\mathrm{PM}_{2.5}$. The traditional approach to source attribution analysis is brute-force or zero-out sensitivity analysis in which the emissions from a given source sector are removed to quantify the contribution of that sector. This approach is expensive and impractical for assessing the contributions of a large number of source categories. Furthermore, it suffers from the limitation that the sum of zero-out impacts over all sources will not equal the total concentration (Koo et al., 2009). Tagged species methods, such as the Ozone and Particulate Source Apportionment Technology (OSAT/PSAT) in CAMx (Dunker et al., 2002; Yarwood et al., 2007), can effi- 
ciently track contributions from many source sectors and/or regions and provide source contributions that sum to the total concentration. These methods are increasingly being used to help understand complex air quality issues (e.g., Wagstrom et al., 2008; Burr and Zhang, 2011; Baker and Kelly, 2014; Collet et al., 2014; Wang et al., 2009; Li et al., 2012; Skyllakou et al., 2014).

Many source attribution studies in Europe have used receptor models and back trajectory analysis for inert pollutants, i.e., primary particulate matter (e.g., Querol et al., 2001, 2004, 2009; Belis et al., 2011, 2013; Viana et al., 2014). Source attribution studies in Europe for secondary pollutants, such as ozone and secondary $\mathrm{PM}_{2.5}$, have used PGMs with the zero-out approach. Skyllakou et al. (2014) used the CAMx PSAT approach to distinguish the contributions of local and regional sources to fine PM in Paris. Reis et al. (2000) studied the impact of road traffic emissions on regional ozone levels in Europe by zeroing out traffic emissions. Derwent et al. (2005) used a similar approach to determine the contribution of shipping emissions to ozone and acid deposition in Europe. Sartelet et al. (2012) estimated the contributions of biogenic and anthropogenic emissions to $\mathrm{O}_{3}$ and $\mathrm{PM}$ concentrations in Europe and North America by zeroing out one source category at a time. Under the TRANSPHORM (Transport related Air Pollution and Health impacts - Integrated Methodologies for Assessing Particulate Matter) program, the source contributions of transport emissions (road transport, shipping, aviation) to $\mathrm{O}_{3}$ and $\mathrm{PM}$ contributions in Europe were assessed using WRF-CMAQ and the zero-out approach (TRANSPHORM, 2014). Derwent et al. (2008) conducted sensitivity studies with a global chemical transport model to understand the effects of longrange transport from North America and Asia to surface ozone in Europe. Aksoyuglu et al. (2016) estimated the contribution of ship emissions to the concentration and deposition of air pollutants in Europe using CAMx with a zero-out approach.

All of the PGM source attribution studies above for Europe investigated the contributions of a limited number of source categories. Examples of European source attribution studies addressing a larger number of source categories include EMEP (2009), Brandt et al. (2013), and Tagaris et al. (2015). The European Monitoring and Evaluation Programme (EMEP) study used $15 \%$ sector-by-sector emission reductions in the Unified EMEP model to determine contributions from different emission sectors to depositions and air concentrations in countries within the EMEP domain for 2006 (EMEP, 2009). Brandt et al. (2013) used the EVA (Economic Valuation of Air Pollution) model system, which includes the Danish Eulerian Hemispheric Model (DEHM), with a tagging approach to evaluate the contributions from the 10 Standard Nomenclature for Air Pollution (SNAP) source sectors to air-pollution-related health costs in Europe and Denmark for the 2000 base year. More recently, Tagaris et al. (2015) used the zero-out approach with CMAQ to calculate the contributions of emissions from the 10 SNAP source sectors to air quality over Europe for a summer month (July 2006).

The study described in this paper differs from and complements the previous source attribution studies. We take advantage of the source apportionment tools (OSAT and PSAT) in CAMx to calculate the contributions of the 10 SNAP sectors, biogenic emissions, dust emissions, and sources outside the modeling domain (boundary conditions) to a large number of cities in Europe. The CAMx modeling database for 2010, developed as part of the Air Quality Model Evaluation International Initiative (AQMEII), is used for the analysis.

AQMEII is a joint regional air quality model evaluation effort between the North American and European modeling communities to improve the understanding of uncertainties in model predictions of ozone and $\mathrm{PM}_{2.5}$ and to use this knowledge to guide model improvements (Rao et al., 2011). In Phase 1 of the AQMEII, a large number of offline photochemical air quality models were applied and evaluated in Europe and North America for the year 2006 using consistent inputs to the extent possible (Rao et al., 2011; Galmarini et al., 2012). The second phase of AQMEII was dedicated to the evaluation of online coupled chemistry-meteorology models over both continents, with a primary focus on the year 2010 (Galmarini et al., 2015). In Phase 3, the focus is on diagnostic evaluation through sensitivity studies on model inputs and spectral decomposition of model errors (Galmarini et al., 2016; Solazzo and Galmarini, 2016; Solazzo et al., 2017), as well as on collaboration with the Task Force on Hemispheric Transport of Air Pollution (TF-HTAP) on coordinating global-hemispheric-regional modeling experiments to characterize long-range transport. As part of Phase 3, a CAMx modeling database has been developed and evaluated for Europe (Solazzo et al., 2017), and this database was used in the study described in this paper.

\section{Model setup}

\subsection{Model configuration, domain, and inputs}

Solazzo et al. (2017) developed a 2010 CAMx database for Europe and applied CAMx version 6.1 (Ramboll Environ, 2014) over the European Union (EU). The simulations used the Carbon Bond 2005 (CB05) gas phase chemistry (Yarwood et al., 2005) and the coarse-fine (CF) aerosol scheme. CAMx was applied for the whole year for a domain covering Europe and a portion of Africa. The domain (see Fig. 1) is defined in a Lambert conic conformal projection that includes 270 by 225 grid cells with a $23 \mathrm{~km}$ horizontal grid resolution.

Input meteorological data were generated using WRFChem 3.4.1, the coupled chemistry version of the Weather Research and Forecasting (WRF) model (Skamarock et al., 2008), driven by the European Centre for Medium-Range 


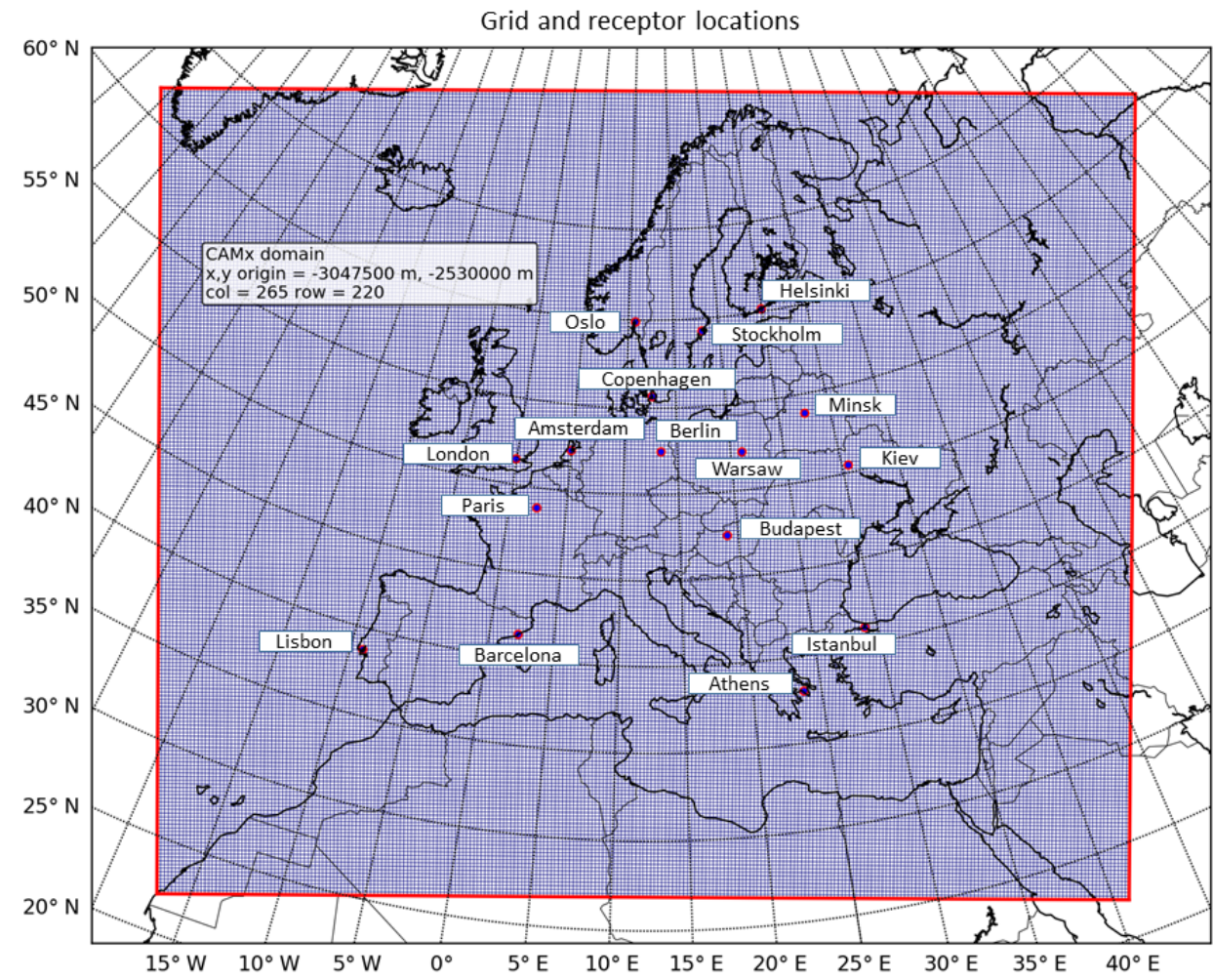

Figure 1. CAMx modeling domain with 270 by 225 grid cells at $23 \mathrm{~km}$ horizontal grid resolution. The figure also shows the 16 cities considered for the source attribution analysis.

Weather Forecasts (ECMWF) analysis fields. WRF-Chem was used rather than WRF to obtain emission estimates for wind-blown dust. Analysis nudging for wind speed, temperature, and water vapor mixing ratio was employed both within and above the boundary layer, with a nudging coefficient of $0.0003 \mathrm{~s}^{-1}$. The WRF vertical grid with 33 layers extends from the surface to a fixed pressure of $50 \mathrm{hPa}$ (about $20 \mathrm{~km}$ ), with a surface layer depth of $24 \mathrm{~m}$. The WRF-CAMx preprocessor (version 4.2; Ramboll Environ, 2014) was used to create CAMx input files, collapsing the 33 layers used by WRF to 14 layers in CAMx, but keeping layers up to $230 \mathrm{~m}$ above ground level identical to the WRF layers.

Anthropogenic emissions for the calendar year 2009 were derived from the TNO-MACC_II emission inventory (Kuenen et al., 2014; Pouliot et al., 2015), resolved by the SNAP sector (see Table 1). The primary data sources were national emission inventories developed by European countries in accordance with guidance provided by the European Environment Agency (EEA, 2013). SNAP sector 34 combines industrial combustion (sector 3) with industrial processes (sector 4) to mitigate inconsistent classification of sources to sector 3 or 4, as discussed by Kuenen et al. (2014). Supplement Sect. A provides a summary of $\mathrm{SO}_{2}, \mathrm{NO}_{x}$, and $\mathrm{PM}_{2.5}$ emissions from the nine SNAP sectors for the summer and winter months and presents spatial maps of total surface emissions and surface emissions for some sectors.
For the road transport sector (SNAP 7), it should be noted that the provided emission inventory does not include information on the composition of the vehicle fleet in different cities in Europe because the emission inventory was made available to the AQME participants with source contributions grouped according the SNAP classification but without any additional information about the car fleet or other proxies introduced in emission computation. However, the MACC-II emission inventory (Kuenen et al., 2014) that was used for this study was constructed by using the reported emission national totals by sector. Therefore, for each country a representative car fleet was used and the differences in fleet composition among different countries are implicitly accounted for in the provided emission inventory. The non-road transport sector (SNAP 8) includes a variety of emission sources, such as off-road transport (shipping, railways, aviation, inland waterways) and machinery (agriculture, forestry, industry, military, airports).

Biogenic volatile organic compound (VOC) emissions were estimated by applying the Model of Emissions of Gases and Aerosols from Nature (MEGAN; Guenther et al., 2012) v2.04. Sea salt emissions were estimated using published algorithms (de Leeuw et al., 2000; Gong, 2003). Dust emissions were based on the GOCART (Ginoux et al., 2001, 2004) model implemented in WRF-Chem (Zhao et al., 2010). Chemical boundary conditions were derived 
Table 1. SNAP sector classification of anthropogenic emissions.

\begin{aligned} & \hline Sector number Description \\ & \hline 1 Energy industries (e.g., power generation and refineries) \\ & 2 Non-industrial (residential) combustion \\ & 34 Industry* \\ & 5 Extraction and distribution of fossil fuels \\ & 6 Solvent and other product use \\ & 7 Road transport (includes exhaust, evaporative, tire-brake-road wear) \\ & 8 Non-road transport (includes rail, aircraft, shipping, construction equipment) \\ & 9 Waste treatment \\ & 10 Agriculture \\ & \hline\end{aligned}

* Sector 34 combines industrial combustion (SNAP 3) with industrial processes (SNAP 4) to mitigate inconsistent

classification of sources to sector 3 or 4 (see Kuenen et al., 2014).

from the Monitoring Atmospheric Composition and Climate (MACC) project using the Composition-Integrated Forecast System (C-IFS) model (Flemming et al., 2015). The MACC data were available at 3 -hourly time intervals with horizontal resolution of $1.125^{\circ} \times 1.125^{\circ}$. Variables were provided as 3-D fields in pressure hybrid vertical coordinates and included gas phase species, namely $\mathrm{CO}, \mathrm{O}_{3}, \mathrm{NO}, \mathrm{NO}_{2}$, PAN, $\mathrm{HNO}_{3}, \mathrm{CH}_{2} \mathrm{O}$ (formaldehyde), $\mathrm{SO}_{2}, \mathrm{H}_{2} \mathrm{O}_{2}, \mathrm{C}_{2} \mathrm{H}_{6}$ (ethane), $\mathrm{CH}_{3} \mathrm{COCH}_{3}$ (acetone), $\mathrm{CH}_{3} \mathrm{OH}$ (methanol), $\mathrm{C}_{3} \mathrm{H}_{8}$ (propane), $\mathrm{C}_{2} \mathrm{H}_{5} \mathrm{OH}$ (ethanol), $\mathrm{C}_{2} \mathrm{H}_{4}$ (ethene), PAR (paraffins), ALD2 (aldehydes), OLE (olefins), $\mathrm{C}_{5} \mathrm{H}_{8}$ (isoprene), $\mathrm{CHOOH}$ (formic acid), $\mathrm{CH}_{3} \mathrm{OOH}$ (methyl peroxide), ONIT (organic nitrates), and aerosol species (dust, sulfate, hydrophobic and hydrophilic organic matter, and hydrophobic and hydrophilic black carbon, BC). Mineral dust aerosols were provided in three different size bins, ranging from 0.03 to $20 \mu \mathrm{m}$. More information on MACC data as well as their evaluation against a set of ground-based measurements can be found in Inness et al. (2013) and Giordano et al. (2015).

\subsection{Model performance evaluation summary}

Solazzo et al. (2017) conducted a detailed model performance evaluation of CAMx for 2010 in the framework of the AQMEII Phase 3 project. Here we present a brief summary of model performance using a set of ground-based observations belonging to the AirBase network (http://www.eea.europa.eu/data-and-maps/data/ airbase-the-european-air-quality-database-8) and covering most of the computational domain. Only background stations are considered in the analysis. Furthermore, analysis was carried out for the whole set, including urban, suburban, and rural sites (all background, $\mathrm{AB}$ ), as well as for rural background sites only (RB). Note that the rural background sites are the most appropriate for model performance evaluation because the coarse resolution $(23 \mathrm{~km})$ used in the simulation cannot reproduce local-scale processes that can take place, particularly within the urban areas, and that can also influence the observed values at background sites.
However, since urban areas were the main focus of the source attribution analysis presented here, the evaluation was performed over background stations, not just the rural background sites. The comparison of the model performance for these two different sets of sites provides a quantitative evaluation of the possible degradation of the CAMx results when evaluated at urban sites, whose spatial representativeness is not always adequate to the model resolution, even for background sites. As noted by Terrenoire et al. (2015), model performance for RB sites is better than for urban background (UB) sites, even when using a fine resolution of $8 \mathrm{~km}$.

The model performance was evaluated over the whole year and based on daily mean concentrations. Only stations that had more than $75 \%$ of data availability on a yearly basis have been included in the comparisons. The number of available stations range according to the chemical species. The highest availability was noted for $\mathrm{NO}_{2}$, with more than 2500 stations. Ozone and $\mathrm{SO}_{2}$ were available at more than 1500 sites, while for $\mathrm{PM}_{10}$ more than 2300 sites were available. $\mathrm{PM}_{2.5}$ observations were available in about 700 sites all over Europe, with about 300 sites corresponding to RB stations. Model performance was also evaluated at city level for selected cities for the winter (January to March) and summer (July to September) seasons of 2010 for consistency with the source attribution analyses described in this paper.

\subsubsection{Annual model performance evaluation for entire domain}

Table 2 provides a domain-wide summary of model performance for the $\mathrm{AB}$ and $\mathrm{RB}$ sets of stations. The statistical performance measures used in the evaluation are defined in Supplement Sect. B (Sect. B1). Correlation refers to the Pearson correlation coefficient $(r)$ and expresses the temporal correlation between the observed and computed daily mean concentrations. The yearly mean of the observed $\mathrm{SO}_{2}$ concentration is $2.3 \mathrm{ppb}$, while the modeled value is 1.2 , corresponding to a $48 \%$ low bias. Similar results are noted at RB sites (nor- 
Table 2. CAMx model performance metrics at all (AB) and rural (RB) background AirBase sites. Metrics are computed for daily mean concentrations for the calendar year 2010.

\begin{tabular}{|c|c|c|c|c|c|c|c|c|c|c|c|c|}
\hline \multirow[b]{2}{*}{ Parameter } & \multicolumn{2}{|c|}{$\mathrm{SO}_{2}[\mathrm{ppb}]$} & \multicolumn{2}{|c|}{$\mathrm{NO}_{2}[\mathrm{ppb}]$} & \multicolumn{2}{|c|}{$\mathrm{O}_{3}[\mathrm{ppb}]$} & \multicolumn{2}{|c|}{$\mathrm{O}_{X}[\mathrm{ppb}]$} & \multicolumn{2}{|c|}{$\mathrm{PM}_{10}\left[\mu \mathrm{g} \mathrm{m}^{-3}\right]$} & \multicolumn{2}{|c|}{$\mathrm{PM}_{2.5}\left[\mu \mathrm{g} \mathrm{m}^{-3}\right]$} \\
\hline & $\mathrm{AB}$ & $\mathrm{RB}$ & $\mathrm{AB}$ & $\mathrm{RB}$ & $\mathrm{AB}$ & $\mathrm{RB}$ & $\mathrm{AB}$ & $\mathrm{RB}$ & $\mathrm{AB}$ & $\mathrm{RB}$ & $\mathrm{AB}$ & $\mathrm{RB}$ \\
\hline \# observations & 550113 & 90446 & 954709 & 141241 & 646965 & 144139 & 561059 & 108438 & 842896 & 115022 & 267121 & 36378 \\
\hline Observed mean & 2.3 & 1.6 & 14.0 & 6.9 & 26.3 & 29.2 & 36.7 & 34.6 & 27.8 & 21.7 & 17.5 & 14.5 \\
\hline Modeled mean & 1.2 & 0.9 & 6.1 & 4.9 & 31.8 & 31.6 & 36.8 & 35.8 & 22.6 & 21.8 & 14.0 & 13.9 \\
\hline Observed SD & 4.6 & 2.2 & 10.1 & 6.1 & 11.3 & 11.1 & 10.3 & 10.1 & 22.0 & 17.0 & 15.9 & 13.5 \\
\hline Modeled SD & 1.4 & 1.0 & 4.8 & 4.2 & 12.0 & 12.2 & 10.6 & 10.7 & 13.8 & 13.5 & 9.2 & 9.2 \\
\hline Mean bias & -1.1 & -0.6 & -7.9 & -2.0 & 5.6 & 2.4 & 0.0 & 1.1 & -5.3 & 0.1 & -3.4 & -0.6 \\
\hline NMB (\%) & -47.9 & -40.9 & -56.3 & -29.4 & 21.1 & 8.2 & 0.0 & 3.3 & -18.9 & 0.4 & -19.7 & -4.2 \\
\hline Mean error & 1.7 & 1.1 & 8.4 & 3.3 & 8.6 & 7.4 & 6.8 & 6.6 & 14.4 & 11.9 & 8.3 & 7.1 \\
\hline NME (\%) & 72.1 & 69.2 & 60.0 & 47.8 & 32.7 & 25.2 & 18.5 & 19.1 & 51.7 & 55.0 & 47.3 & 49.3 \\
\hline FB (\%) & -45.4 & -37.6 & -73.1 & -29.3 & 19.7 & 6.4 & -0.3 & 2.9 & -15.4 & 3.5 & -13.7 & 4.2 \\
\hline FE $(\%)$ & 81.9 & 76.5 & 81.6 & 55.6 & 33.5 & 28.2 & 19.5 & 20.0 & 53.1 & 52.6 & 49.8 & 50.1 \\
\hline Correlation & 0.24 & 0.32 & 0.52 & 0.59 & 0.66 & 0.69 & 0.64 & 0.67 & 0.28 & 0.30 & 0.48 & 0.52 \\
\hline RMSE & 4.6 & 2.2 & 11.7 & 5.4 & 11.1 & 9.5 & 8.9 & 8.5 & 23.1 & 18.3 & 14.5 & 11.8 \\
\hline IoA & 0.3 & 0.5 & 0.6 & 0.7 & 0.8 & 0.8 & 0.8 & 0.8 & 0.5 & 0.5 & 0.6 & 0.7 \\
\hline
\end{tabular}

malized mean bias, $\mathrm{NMB}=-41 \%)$. $\mathrm{NO}_{2}$ yearly mean concentrations are clearly underestimated when all background sites are considered. However, when the analysis is limited only to RB sites, which are more suitable for comparisons with a model run using a $23 \mathrm{~km}$ horizontal grid resolution, there is a noticeable improvement in model performance. The NMB improves from -56.3 to $-29.4 \%$ and the normalized mean error (NME) decreases from 60 to $47.8 \%$. As a consequence, the RMSE drops from 11.7 to $5.4 \mathrm{ppb}$, and the daily correlation grows from 0.52 to 0.60 . The underestimation of $\mathrm{NO}_{2}$ concentrations may be because the grid resolution is too coarse to resolve many of the monitoring locations, or alternatively it may indicate that $\mathrm{NO}_{x}$ emissions are underestimated in this inventory.

Annual mean ozone concentrations at AB sites are overestimated ( $\mathrm{NMB}=21.1 \%$ ), while the standard deviation (SD) of the yearly series is correctly reproduced (standard deviation of $11.3 \mathrm{ppb}$ observed versus $12 \mathrm{ppb}$ modeled). Similar performance for $\mathrm{SD}$ is observed at RB sites, together with a clear improvement in terms of the yearly mean, as pointed out by the decrease in NMB and NME. These results suggest that the ozone bias at $\mathrm{AB}$ sites is partially due to overestimation at urban and suburban sites, where the horizontal grid resolution is insufficient to resolve ozone suppression at monitors of nearby sources of $\mathrm{NO}_{x}$. This hypothesis is confirmed by analysis of the $\mathrm{O}_{x}$ concentration $\left(\mathrm{O}_{x}=\mathrm{O}_{3}+\mathrm{NO}_{2}\right)$, which removes the local effect of $\mathrm{NO}_{x}$ titration. $\mathrm{O}_{x}$ concentrations at both $\mathrm{AB}$ and $\mathrm{RB}$ sites are very well reproduced in terms of both mean and SD. Also, the temporal variation of $\mathrm{O}_{x}$ concentrations is well reproduced, as shown by the correlation value ( 0.64 and 0.67 at $\mathrm{AB}$ and $\mathrm{RB}$ sites, respectively).

$\mathrm{PM}_{10}$ concentrations are underestimated at $\mathrm{AB}$ sites (NMB $=-19 \%)$, but the bias for RB sites is small (NMB $=0.4 \%$ and fractional bias $(\mathrm{FB})=3.5 \%)$. Conversely, the NME (and fractional error, FE) remains high for both sets of stations. In particular, the NME increases from $51.7 \%$ at $\mathrm{AB}$ sites to $55 \%$ at $\mathrm{RB}$ sites. The temporal correlations are also low $(<0.3)$ in both cases. The overall performance suggests that CAMx correctly captured the yearly mean burden of aerosol but not its temporal evolution. This could be due to compensating errors among different sources that could be either underestimated or overestimated. The correlations for $\mathrm{PM}_{2.5}$ are better (correlation $=0.48$ and 0.52 at $\mathrm{AB}$ and $\mathrm{RB}$ sites, respectively), although there is more underestimation bias for $\mathrm{PM}_{2.5}$ than for $\mathrm{PM}_{10}$. These results suggest that coarse PM mass is likely overestimated and its temporal evolution is not correctly reproduced by CAMx. Note that a large fraction of the coarse PM can be attributed to dust and/or sea salt sources and there are large uncertainties in estimating emissions from these sources.

Supplement Sect. B provides additional details and discussion on the spatial and temporal annual performance of the model. Below, we present model performance results for specific cities during the winter and summer.

\subsubsection{Seasonal model performance evaluation for selected cities}

Model performance was also evaluated at those cities selected for source apportionment analysis (see Sect. 2.3 for the selected cities) that had available background stations. For each city, all AirBase background stations belonging to an area of about $50 \times 50 \mathrm{~km}^{2}$ placed around the city were selected. For all cities, at least two sites were included when available. The analysis was carried out over two quarters: January-March and July-September 2010. The two quarters cover the months of February and August that were selected for SA analysis. Ozone was evaluated only for the summer season, while $\mathrm{PM}_{2.5}$ was evaluated for both periods. Model performance evaluation (MPE) was based on the same indi- 
cators used for the performance analysis of the annual results (see Sect. B1 in Supplement B).

The performance evaluation results for summer ozone are summarized in Table 3 and Figs. 2 and 3. CAMx reproduced the ozone summer mean fairly well, though it showed a slight and systematic overestimation. FB was lower than $20 \%$ at all sites, except for two cities in eastern Europe, Warsaw (24\%) and Budapest (35\%). Temporal correlations ranged between 0.6 and 0.8 for all sites, with the exception of two Mediterranean sites, Barcelona and Athens, where the correlation dropped to 0.4. As shown in Fig. 3, the degradation in correlation in Barcelona is due to an overestimation taking place in July and September, while in August ozone concentrations were correctly captured. In contrast, the worsening in model performance at Athens is probably due to the higher variability, in both space and time, shown by observed data, which is not captured by CAMx.

The analysis of CAMx time series of ozone concentrations illustrates the systematic overestimation in Budapest for all percentiles, while in Warsaw the overestimation is primarily associated with the median and the third quartile. At all other sites, CAMx is able to capture both the seasonal trend, slightly decreasing from July to September, as well as the development of most of the short-term episodes (e.g., during the first and second half of July in Lisbon, Paris, Berlin, Amsterdam, and London).

$\mathrm{PM}_{2.5}$ was evaluated for both summer and winter. During the warm season, the observed mean concentration ranges between 6 and $14 \mu \mathrm{g} \mathrm{m}^{-3}$ (see Table 4 and Fig. 4), except in Athens and Warsaw, where the seasonal values are around 25 and $20 \mu \mathrm{g} \mathrm{m}^{-3}$, respectively. $\mathrm{PM}_{2.5}$ mean concentrations were underestimated at most sites, with FB substantially close to 0 in Copenhagen and London and ranging between -5 and $-20 \%$ in Barcelona, Lisbon, Berlin, Oslo, and Helsinki. As already mentioned, the worst performance was for Athens and Warsaw. Finally, $\mathrm{PM}_{2.5}$ concentrations are partially overestimated in Paris and Amsterdam. FE is generally lower than $40 \%$, again with the exception of Athens and Warsaw, proving that, beyond the mean values, the whole distribution of the daily mean concentrations is also reproduced fairly well. Conversely, temporal correlations range between 0.2 and 0.6 , pointing out the model difficulty in capturing the exact temporal variability of the observed values. As shown in Fig. 5, this is probably due to the very low variability of the observed concentrations over the summer season. At the Lisbon site, CAMx strongly overestimates an episode, showing a concentration of about twice the observed one, which is probably due to a corresponding overestimation of the contribution of the natural sources (e.g., sea salt).

During winter, CAMx is partially able to capture the spatial variability of the observed concentrations, which range between $9 \mu \mathrm{g} \mathrm{m}^{-3}$ (Lisbon) and $42 \mu \mathrm{g} \mathrm{m}^{-3}$ (Warsaw), as shown in Table 5 and Fig. 6. CAMx clearly underestimates the seasonal mean concentration in Warsaw $(\mathrm{FB}=-40 \%)$ and Berlin $(\mathrm{FB}=-20 \%)$, which show the highest observed values, as well as in Athens and Barcelona $(\mathrm{FB}=-36 \%)$. Discrepancies between modeled and measured values in eastern Europe are mainly related to the underestimation of several very strong episodes taking place over the area in January (Fig. 7). However, CAMx performs better in February (the month used for the SA analysis) and March. CAMx correctly reproduces the mean concentrations in central-western Europe (London, Paris, and Amsterdam), while it partially overestimates the observations at northern European sites. The latter is probably due to an overestimation of the sea salt contribution.

The seasonal analysis performed at city level shows that CAMx is generally able to capture the spatial and temporal patterns of the pollutant concentrations across Europe, providing confidence in the different source contributions estimated at each city, discussed in the following section. Moreover, in the case of $\mathrm{PM}_{2.5}$, CAMx is also able to correctly capture the seasonal variations.

\subsection{Source attribution modeling}

The source attribution modeling with CAMx used the OSAT and PSAT tagged species methods in CAMx version 6.1 (Ramboll Environ, 2014). In addition to the SNAP sector emission categories, the contributions of biogenic emissions, dust and sea salt emissions (for PM), and boundary conditions of model chemical species were explicitly tracked. Secondary organic aerosol (SOA) was not apportioned by PSAT because of the high computer memory requirement to track SOA categories on the large CAMx modeling grid. The total biogenic and anthropogenic SOA were both available from the CAMx CF aerosol scheme. Note that the PSAT approach apportions contributions to PM species independently and can thus handle particulate ammonium having different source contributions (e.g., from agriculture) than particulate nitrate (e.g., from urban traffic emissions).

The source attribution simulations were conducted for a summer month (August 2010) and a winter month (February 2010). Although a model spin-up period of 1 week (last week of January 2010 for the winter simulation and the last week of July 2010 for the summer simulation) was used to minimize the influence of initial conditions, the contributions of initial conditions to surface ozone and PM concentrations are included in the boundary condition attribution component in the discussion of results in the following section.

\section{Results}

We selected 16 cities, representing the Nordic countries; countries in western, central, and eastern Europe; and countries along the Mediterranean coastline, for the source attribution analysis. The contributions of the various source sectors to ozone and $\mathrm{PM}_{2.5}$ concentrations were calculated for these cities and are discussed in this section. The calcula- 

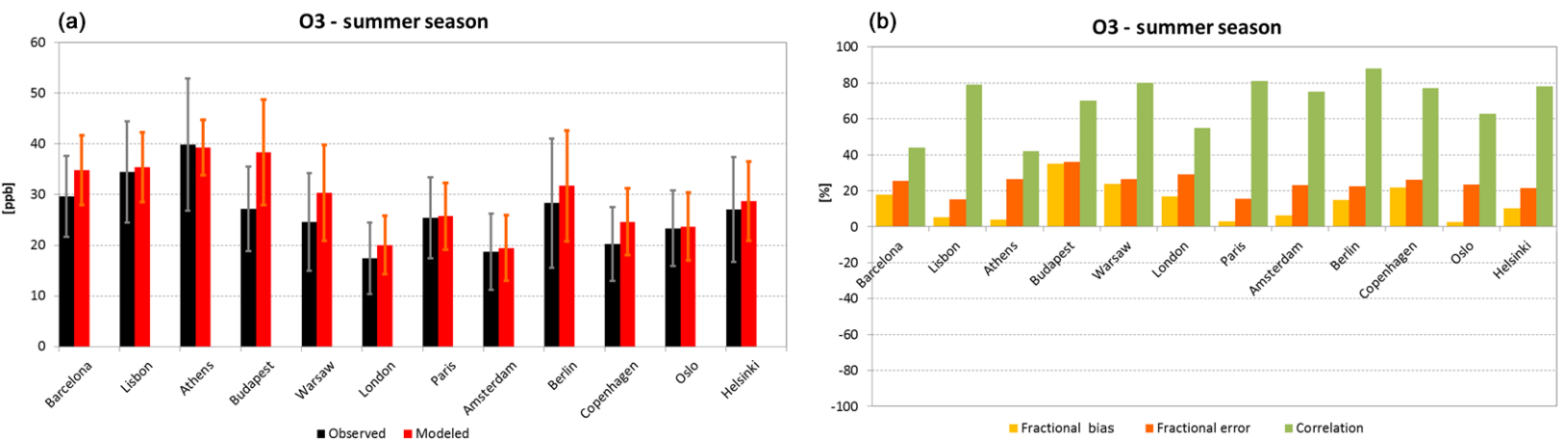

Figure 2. Evaluation of CAMx model performance for $\mathrm{O}_{3}$ at selected cities for 1 July to 30 September 2010. (a) Comparison of the observed (black) and modeled (red) seasonal mean concentrations. Bars show the corresponding observed (grey) and modeled (orange) standard deviations. (b) The seasonal fractional bias (orange), fractional error (red), and correlation (green) computed for each city.
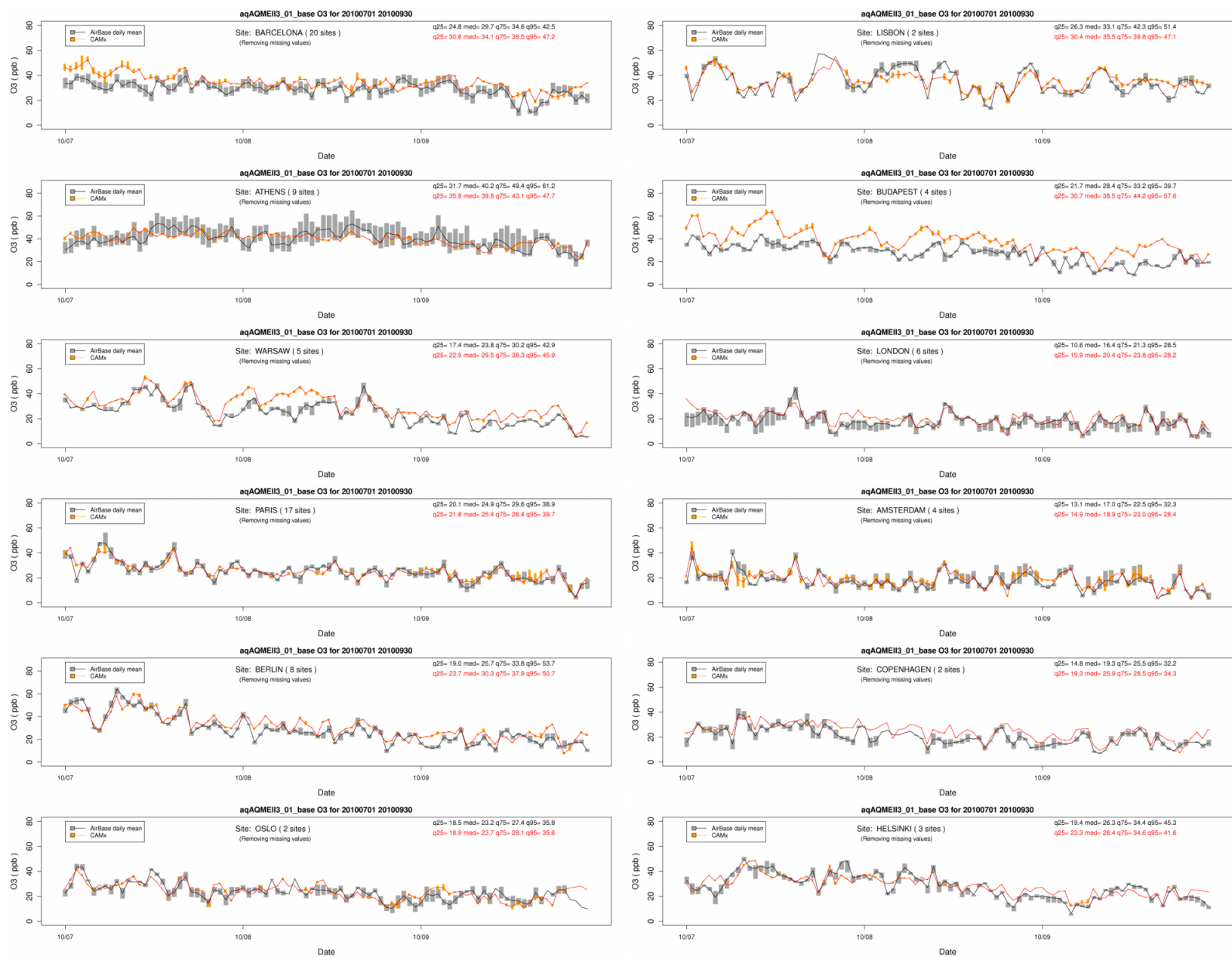

Figure 3. Time series of the box and whisker plots for the distribution of the observed (black and grey) and computed (red and orange) daily concentrations of $\mathrm{O}_{3}$ at background AirBase sites in the selected cities for 1 July-30 September 2010. Bars show the interquartile range and lines show the median values. Values for the 25th, 50th, 75th, and 95th quantiles are also reported for each city. 
Table 3. Summary of CAMx model performance evaluated at background AirBase sites belonging to the selected cities. Statistics are computed for daily mean $\mathrm{O}_{3}$ concentrations over the summer season (1 July-30 September).

\begin{tabular}{|c|c|c|c|c|c|c|c|c|c|c|c|c|c|c|}
\hline City & $\begin{array}{r}\# \\
\text { obs. }\end{array}$ & $\begin{array}{c}\text { Obs. } \\
\text { mean }\end{array}$ & $\begin{array}{r}\text { Model } \\
\text { mean }\end{array}$ & $\begin{array}{r}\text { Obs. } \\
\text { SD }\end{array}$ & $\begin{array}{r}\text { Model } \\
\text { SD }\end{array}$ & $\begin{array}{r}\text { Mean } \\
\text { bias }\end{array}$ & $\begin{array}{r}\mathrm{NMB} \\
(\%)\end{array}$ & $\begin{array}{l}\text { Mean } \\
\text { error }\end{array}$ & $\begin{array}{r}\mathrm{NME} \\
(\%)\end{array}$ & $\begin{array}{l}\text { FB } \\
(\%)\end{array}$ & $\begin{array}{c}\mathrm{FE} \\
(\%)\end{array}$ & Corr. & RMSE & IoA \\
\hline Amsterdam & 327 & 18.7 & 19.4 & 7.6 & 6.5 & 0.7 & 3.9 & 4.0 & 21.3 & 6.1 & 23.0 & 0.75 & 5.1 & 0.86 \\
\hline Budapest & 341 & 27.2 & 38.3 & 8.3 & 10.4 & 11.1 & 40.9 & 11.4 & 42.1 & 35.0 & 36.2 & 0.70 & 13.4 & 0.62 \\
\hline Helsinki & 265 & 27.0 & 28.7 & 10.3 & 7.8 & 1.7 & 6.3 & 5.3 & 19.4 & 10.2 & 21.4 & 0.78 & 6.6 & 0.86 \\
\hline Oslo & 178 & 23.3 & 23.7 & 7.4 & 6.7 & 0.4 & 1.5 & 5.0 & 21.4 & 2.5 & 23.4 & 0.63 & 6.1 & 0.79 \\
\hline Athens & 816 & 39.9 & 39.3 & 13.1 & 5.5 & -0.6 & -1.4 & 9.6 & 24.2 & 3.8 & 26.3 & 0.42 & 11.9 & 0.52 \\
\hline Barcelona & 1769 & 29.6 & 34.8 & 8.0 & 6.9 & 5.2 & 17.5 & 7.7 & 26.1 & 18.0 & 25.5 & 0.44 & 9.5 & 0.60 \\
\hline Berlin & 735 & 28.3 & 31.7 & 12.8 & 10.9 & 3.4 & 12.1 & 5.7 & 20.0 & 14.9 & 22.4 & 0.88 & 6.9 & 0.91 \\
\hline Copenhagen & 178 & 20.2 & 24.6 & 7.3 & 6.6 & 4.4 & 21.7 & 5.3 & 26.1 & 21.8 & 26.1 & 0.77 & 6.4 & 0.80 \\
\hline Lisbon & 179 & 34.4 & 35.4 & 10.0 & 6.8 & 1.0 & 2.9 & 5.0 & 14.7 & 5.3 & 15.1 & 0.79 & 6.3 & 0.85 \\
\hline London & 428 & 17.4 & 20.1 & 7.0 & 5.7 & 2.7 & 15.3 & 4.9 & 28.1 & 16.8 & 29.2 & 0.55 & 6.7 & 0.72 \\
\hline Paris & 1517 & 25.4 & 25.7 & 8.0 & 6.6 & 0.3 & 1.2 & 3.7 & 14.6 & 3.0 & 15.5 & 0.81 & 4.7 & 0.89 \\
\hline Warsaw & 451 & 24.6 & 30.3 & 9.6 & 9.5 & 5.8 & 23.5 & 6.6 & 26.7 & 23.8 & 26.3 & 0.80 & 8.3 & 0.82 \\
\hline
\end{tabular}

Table 4. Summary of CAMx model performance evaluated at background AirBase sites belonging to the selected cities. Statistics are computed for daily mean $\mathrm{PM}_{2.5}$ concentrations over the summer season (1 July-30 September).

\begin{tabular}{|c|c|c|c|c|c|c|c|c|c|c|c|c|c|c|}
\hline City & $\begin{array}{r}\# \\
\text { obs. }\end{array}$ & $\begin{array}{l}\text { Obs. } \\
\text { mean }\end{array}$ & $\begin{array}{r}\text { Model } \\
\text { mean }\end{array}$ & $\begin{array}{r}\text { Obs. } \\
\text { SD }\end{array}$ & $\begin{array}{r}\text { Model } \\
\text { SD }\end{array}$ & $\begin{array}{r}\text { Mean } \\
\text { bias }\end{array}$ & $\begin{array}{r}\mathrm{NMB} \\
(\%)\end{array}$ & $\begin{array}{r}\text { Mean } \\
\text { error }\end{array}$ & $\begin{array}{r}\mathrm{NME} \\
(\%)\end{array}$ & $\begin{array}{l}\text { FB } \\
(\%)\end{array}$ & $\begin{array}{r}\mathrm{FE} \\
(\%)\end{array}$ & Corr. & RMSE & IoA \\
\hline Amsterdam & 204 & 11.5 & 13.6 & 5.3 & 4.8 & 2.1 & 18.3 & 4.6 & 40.3 & 18.9 & 37.9 & 0.38 & 6.0 & 0.62 \\
\hline Helsinki & 541 & 9.6 & 8.9 & 6.9 & 6.4 & -0.6 & -6.8 & 4.4 & 46.1 & -6.4 & 47.7 & 0.51 & 6.6 & 0.70 \\
\hline Oslo & 533 & 8.1 & 7.7 & 2.9 & 3.6 & -0.4 & -4.9 & 2.8 & 34.3 & -11.0 & 37.5 & 0.43 & 3.5 & 0.65 \\
\hline Athens & 163 & 25.2 & 14.0 & 8.0 & 6.4 & -11.2 & -44.4 & 11.5 & 45.7 & -60.0 & 61.6 & 0.57 & 13.1 & 0.55 \\
\hline Barcelona & 630 & 13.8 & 11.1 & 5.4 & 5.0 & -2.7 & -19.6 & 5.4 & 39.3 & -22.5 & 41.7 & 0.22 & 7.1 & 0.51 \\
\hline Berlin & 537 & 13.0 & 8.7 & 5.0 & 3.3 & -4.3 & -33.3 & 5.3 & 40.9 & -37.9 & 48.1 & 0.30 & 6.7 & 0.53 \\
\hline Copenhagen & 172 & 10.3 & 10.4 & 4.0 & 4.6 & 0.1 & 1.3 & 3.7 & 36.2 & -2.3 & 36.5 & 0.38 & 4.8 & 0.62 \\
\hline Lisbon & 172 & 11.3 & 10.1 & 5.7 & 8.6 & -1.3 & -11.1 & 5.4 & 47.8 & -11.2 & 50.8 & 0.48 & 7.8 & 0.66 \\
\hline London & 560 & 10.7 & 10.5 & 4.0 & 4.3 & -0.2 & -1.9 & 3.9 & 36.5 & -3.8 & 35.7 & 0.24 & 5.1 & 0.54 \\
\hline Paris & 430 & 11.0 & 12.6 & 4.7 & 5.0 & 1.6 & 14.7 & 3.9 & 35.0 & 15.5 & 32.6 & 0.55 & 4.8 & 0.72 \\
\hline Warsaw & 276 & 19.9 & 9.7 & 9.0 & 5.3 & -10.2 & -51.3 & 11.2 & 56.3 & -67.1 & 73.1 & 0.29 & 13.6 & 0.49 \\
\hline Stockholm & 482 & 7.2 & 6.8 & 4.0 & 2.9 & -0.4 & -5.0 & 3.1 & 43.5 & -1.2 & 42.0 & 0.25 & 4.4 & 0.50 \\
\hline
\end{tabular}

tions were conducted using horizontal bilinear interpolation over eight grid cells around each city location.

\subsection{Ozone source apportionment - summer}

The European standard for ozone is based on the maximum daily $8 \mathrm{~h}$ mean (not to exceed a threshold of $120 \mu \mathrm{g} \mathrm{m}^{-3}$, about $60 \mathrm{ppb}$, for 25 days averaged over 3 years). Accordingly, the source apportionment results for ozone are presented for the maximum daily $8 \mathrm{~h}$ average (referred to as H1MDA8) for the summer month. Ozone results for the winter month are not discussed here because H1MDA8 levels at all the selected cities are less than the threshold and because boundary conditions dominate the ozone levels in winter, with contributions at the 16 cities ranging from a low of $61 \%$ to a high of $96 \%$. The spatial pattern of calculated H1MDA8 ozone concentrations across the modeling domain is shown in Fig. C1 in Supplement C. Over most of western and northern Europe, ozone levels are below $60 \mathrm{ppb}$. The highest ozone values (about $120 \mathrm{ppb}$ ) are predicted near Moscow, Russia.
The $60 \mathrm{ppb}$ level is exceeded in some of the Mediterranean countries and in parts of central and eastern Europe.

The source attribution results for summertime H1MDA8 ozone in each city are reported in Table 6 for contributors of $5 \%$ or more. In the four cities near the Mediterranean from Lisbon, Portugal, in the west to Istanbul, Turkey, in the east, H1MDA8 ozone in August 2010 is estimated to be above or very close to the standard of $60 \mathrm{ppb}$. Boundary conditions are the largest contributor to H1MDA8 ozone in all four Mediterranean cities, with contributions ranging from 26 to $34 \%$ from east (Istanbul, Athens) to west (Barcelona, Lisbon). Contributions from on-road transport (SNAP 7) are the next largest (20 to $24 \%$ ) at three of the four cities (Lisbon, Barcelona, Athens). At Istanbul, the second highest contribution $(24 \%)$ comes from biogenic emissions, while on-road transport is the third largest contributor at $15 \%$. Non-road transport (SNAP 8; 12 to $18 \%$ contribution) and biogenic emissions ( 15 to $24 \%$ contribution) are also significant contributors at all four locations. The other anthropogenic sec- 

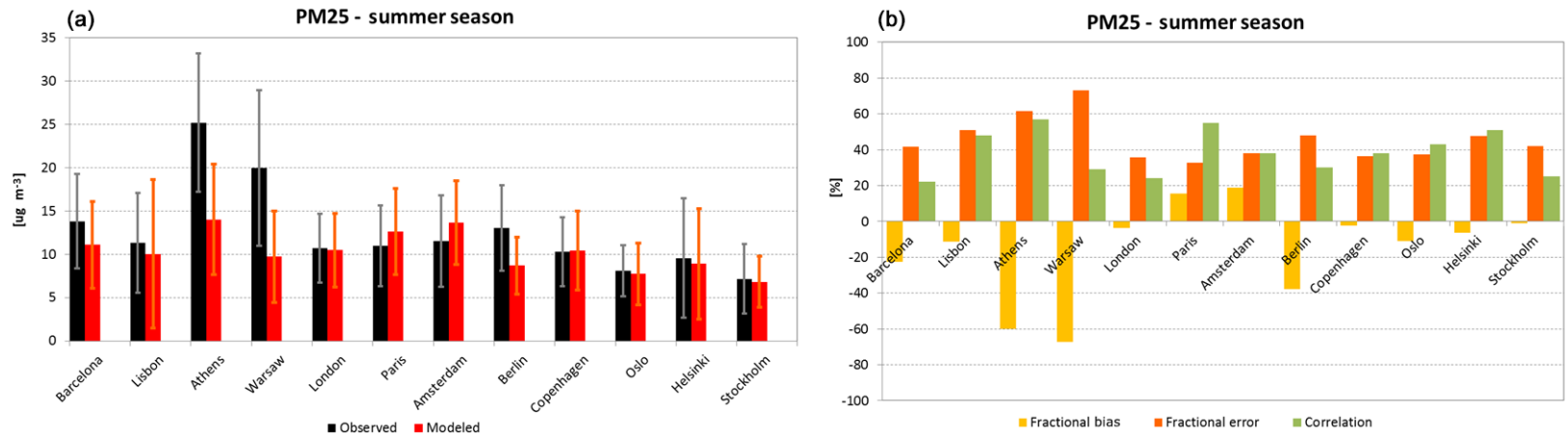

Figure 4. Evaluation of CAMx model performance for $\mathrm{PM}_{2.5}$ at selected cities for July 1 to September 30, 2010. (a) Comparison of the observed (black) and modeled (red) seasonal mean concentrations. Bars show the corresponding observed (grey) and modeled (orange) standard deviation. (b) The seasonal fractional bias (orange), fractional error (red), and correlation (green) computed for each city.

Table 5. Summary of CAMx model performance evaluated at background AirBase sites belonging to the selected cities. Statistics are computed for daily mean $\mathrm{PM}_{2.5}$ concentrations over the winter season (1 January-31 March).

\begin{tabular}{|c|c|c|c|c|c|c|c|c|c|c|c|c|c|c|}
\hline City & $\begin{array}{r}\# \\
\text { obs. }\end{array}$ & $\begin{array}{l}\text { Obs. } \\
\text { mean }\end{array}$ & $\begin{array}{r}\text { Model } \\
\text { mean }\end{array}$ & $\begin{array}{r}\text { Obs. } \\
\text { SD }\end{array}$ & $\begin{array}{r}\text { Model } \\
\text { SD }\end{array}$ & $\begin{array}{r}\text { Mean } \\
\text { bias }\end{array}$ & $\begin{array}{r}\mathrm{NMB} \\
(\%)\end{array}$ & $\begin{array}{l}\text { Mean } \\
\text { error }\end{array}$ & $\begin{array}{r}\mathrm{NME} \\
(\%)\end{array}$ & $\begin{array}{l}\text { FB } \\
(\%)\end{array}$ & $\begin{array}{c}\mathrm{FE} \\
(\%)\end{array}$ & Corr. & RMSE & IoA \\
\hline Amsterdam & 260 & 25.6 & 23.6 & 19.6 & 11.3 & -2.0 & -7.7 & 10.3 & 40.3 & 3.1 & 38.6 & 0.56 & 16.3 & 0.67 \\
\hline Budapest & 104 & 28.0 & 21.9 & 15.7 & 10.0 & -6.1 & -21.8 & 10.9 & 38.9 & -17.4 & 41.5 & 0.38 & 16.2 & 0.59 \\
\hline Helsinki & 507 & 11.8 & 18.1 & 6.4 & 8.3 & 6.3 & 53.3 & 8.1 & 68.7 & 42.8 & 55.0 & 0.34 & 10.6 & 0.51 \\
\hline Oslo & 532 & 15.9 & 18.7 & 9.6 & 11.7 & 2.8 & 17.8 & 11.2 & 70.7 & 14.9 & 59.2 & -0.14 & 16.4 & 0.21 \\
\hline Athens & 212 & 19.3 & 12.9 & 11.4 & 9.4 & -6.4 & -33.3 & 9.2 & 47.5 & -36.4 & 50.3 & 0.34 & 13.7 & 0.56 \\
\hline Barcelona & 404 & 19.3 & 12.5 & 9.8 & 4.8 & -6.9 & -35.6 & 8.8 & 45.3 & -36.1 & 50.2 & 0.31 & 11.7 & 0.51 \\
\hline Berlin & 431 & 34.7 & 24.1 & 26.1 & 11.1 & -10.5 & -30.4 & 16.9 & 48.7 & -18.1 & 48.3 & 0.45 & 25.6 & 0.56 \\
\hline Copenhagen & 164 & 13.9 & 20.9 & 7.9 & 10.6 & 7.1 & 51.2 & 9.7 & 70.0 & 36.2 & 54.2 & 0.42 & 12.5 & 0.57 \\
\hline Lisbon & 167 & 8.6 & 10.4 & 4.8 & 4.8 & 1.8 & 21.3 & 5.0 & 58.2 & 22.4 & 53.2 & 0.14 & 6.6 & 0.45 \\
\hline London & 499 & 18.0 & 20.6 & 10.2 & 9.0 & 2.6 & 14.4 & 7.2 & 39.8 & 16.5 & 37.3 & 0.58 & 9.2 & 0.74 \\
\hline Paris & 323 & 24.3 & 25.4 & 14.3 & 11.8 & 1.0 & 4.2 & 10.4 & 42.6 & 10.0 & 43.1 & 0.50 & 13.3 & 0.68 \\
\hline Warsaw & 278 & 42.4 & 26.3 & 21.7 & 13.2 & -16.1 & -38.0 & 18.4 & 43.4 & -43.4 & 51.7 & 0.51 & 24.7 & 0.60 \\
\hline Stockholm & 491 & 9.6 & 14.2 & 6.1 & 7.8 & 4.6 & 48.4 & 6.8 & 71.3 & 34.6 & 54.8 & 0.38 & 9.1 & 0.56 \\
\hline
\end{tabular}

tors contributing $5 \%$ or more to summertime ozone in the Mediterranean cities are industry (SNAP 34; 6 to $8 \%$ contribution) and the energy sector (SNAP 1; 5 to $8 \%$ contribution).

Boundary conditions are again an important contributor in the four cities in central and eastern Europe, making the largest contributions in Minsk (25\%) and Warsaw $(28 \%)$ and the second largest contributions in Budapest (29\%) and Kiev $(21 \%)$. Road transport is the largest contributor $(35 \%)$ in Budapest, while biogenic emissions are the largest contributor (33\%) in Kiev. Road transport is the second largest contributor in Warsaw (25\%) and biogenic emissions are the second largest contributor $(23 \%)$ in Minsk. Biogenic emissions contribute less in Budapest (10\%) and Warsaw (14\%) than in the other two cities. Other important contributing source sectors in the central and eastern European cities are the energy sector (9\% in Kiev to $17 \%$ in Warsaw), the nonroad sector ( 7 to $10 \%$ contribution), and the industry sector (5 to $7 \%$ contribution).
In all four cities in western Europe (Paris, London, Amsterdam, and Berlin), H1MDA8 ozone concentrations are below the $60 \mathrm{ppb}$ threshold. Boundary conditions are the largest contributor ( 29 to $59 \%$ ) to HD1MA8 ozone at all four cities and contribute more than half the HD1MA8 ozone in London and Paris and nearly $50 \%$ in Berlin. Road transport is the next largest contributor in Paris (13\%) and Berlin (17\%), while non-road transport $(12 \%)$ and biogenic emissions $(21 \%)$ are the second largest contributors in London and Amsterdam. For London, the most relevant non-road transport emissions are likely due to the very intense shipping activity along the English Channel, resulting in large $\mathrm{NO}_{x}$ emissions (see, for example, Fig. 8 in Kuenen et al., 2014). Road transport contributions in London and Amsterdam rank third at 11 and $19 \%$, respectively. Non-road transport contributes less than $10 \%$ to HD1MA8 ozone in Paris, Amsterdam, and Berlin. The energy sector is an important contributor (13\%) in Berlin and contributes 5 to $6 \%$ in London and Amsterdam. The energy sector contribution in Paris is small (less than $3 \%$ ) since France derives over $75 \%$ of 

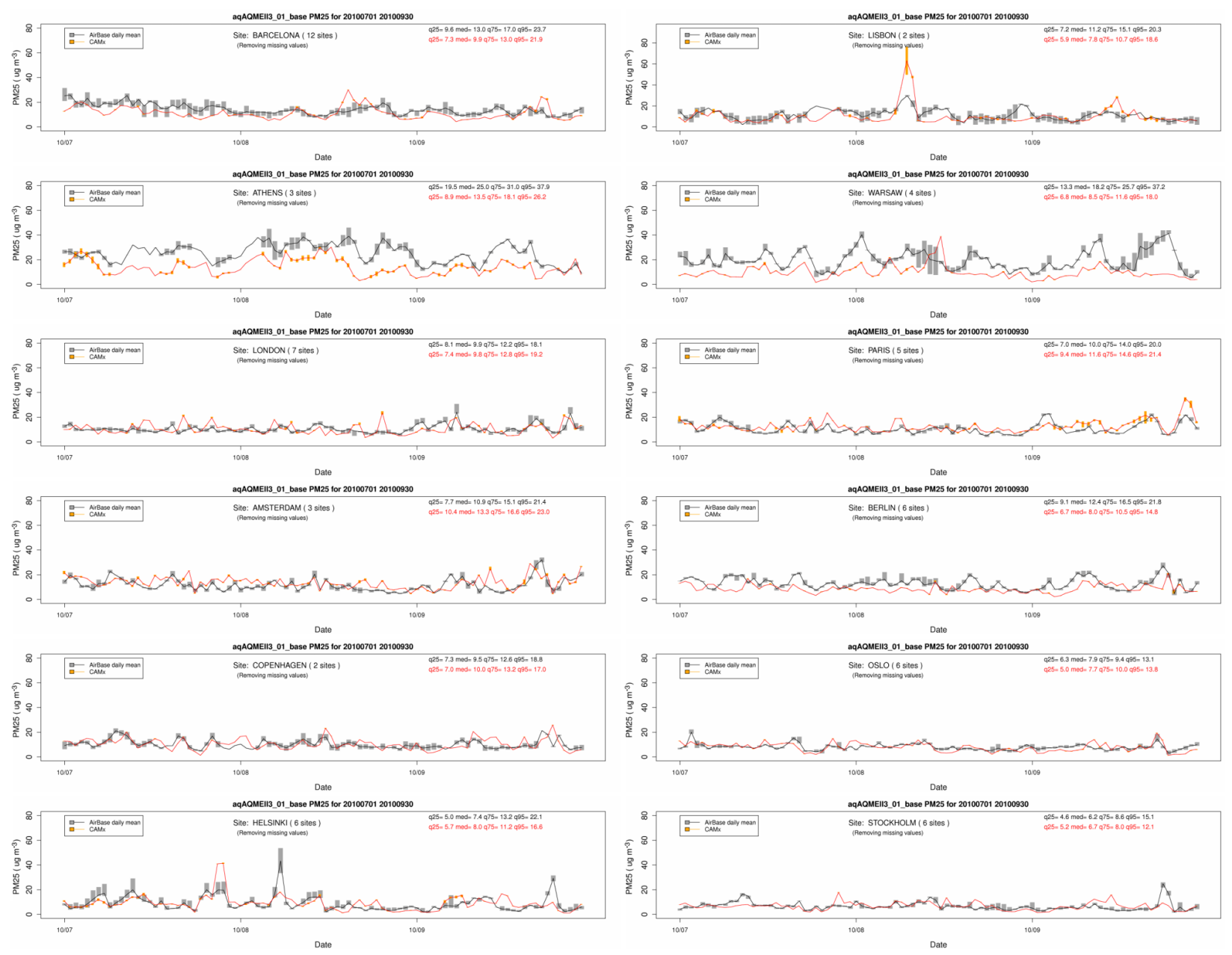

Figure 5. Time series of the box and whisker plots for the distribution of the observed (black and grey) and computed (red and orange) daily concentrations of $\mathrm{PM}_{2.5}$ at background AirBase sites in the selected cities for 1 July-30 September 2010. Bars show the interquartile range and lines show the median values. Values for the 25th, 50th, 75th, and 95th quantiles are also reported for each city.
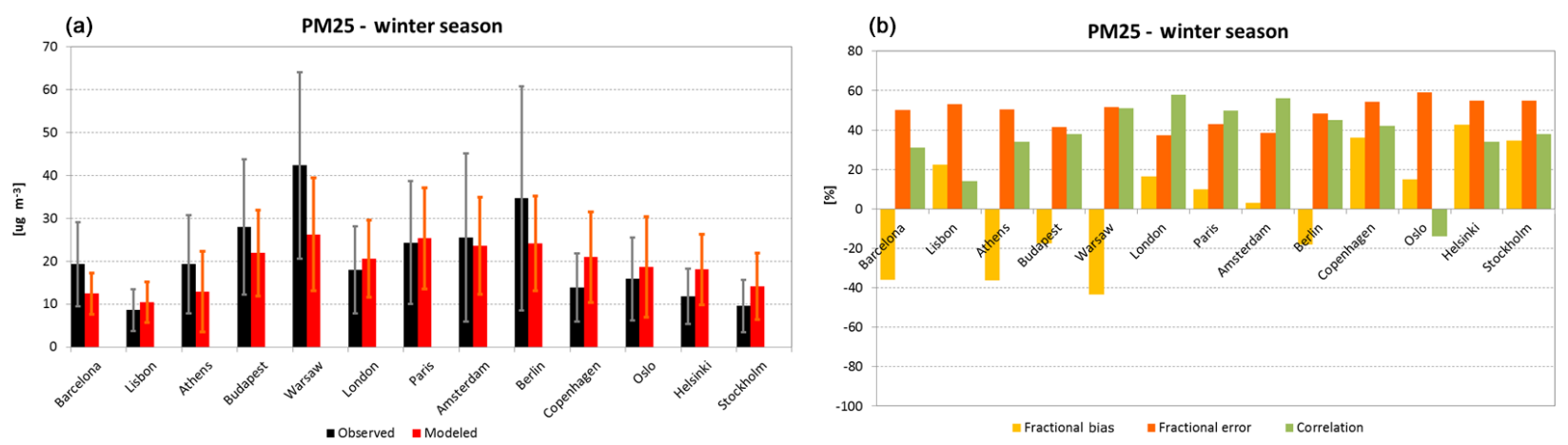

Figure 6. Evaluation of CAMx model performance for $\mathrm{PM}_{2.5}$ at selected cities from 1 January to 31 March 2010. (a) Comparison of the observed (black) and modeled (red) seasonal mean concentrations. Bars show the corresponding observed (grey) and modeled (orange) standard deviation. (b) The seasonal fractional bias (orange), fractional error (red), and correlation (green) computed for each city. 

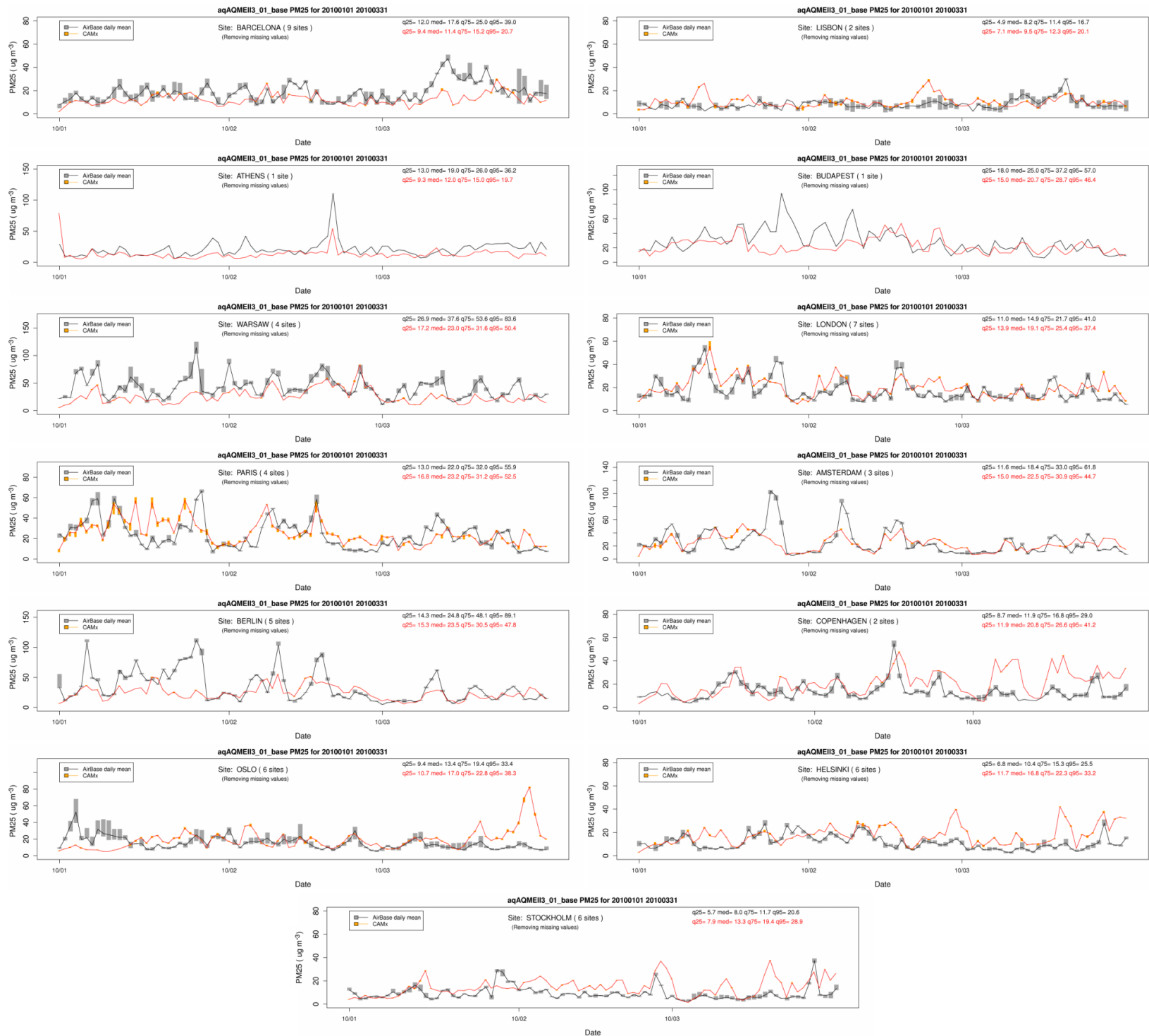

Figure 7. Time series of the box and whisker plots for the distribution of the observed (black and grey) and computed (red and orange) daily concentrations of $\mathrm{PM}_{2.5}$ at background AirBase sites in the selected cities for 1 January-31 March 2010. Bars show the interquartile range and lines show the median values. Values for the 25th, 50th, 75th, and 95th quantiles are also reported for each city.

its electricity from nuclear energy. The solvent- and productuse sector (SNAP 6) contributes 6 and $10 \%$ to summertime ozone in Paris and Amsterdam, respectively, but its contributions in London and Berlin are less than $3 \%$.

Like the selected cities in western Europe, H1MDA8 ozone levels in the Nordic cities (Oslo, Copenhagen, Stockholm, Helsinki) are below the European threshold of $60 \mathrm{ppb}$. Boundary conditions again play an important role for ozone in these cities and are the largest contributors in three of the four cities. Road transport is the largest contributor (24\%) in Stockholm, followed by boundary conditions $(21 \%)$. Road transport contributions to the other three cities range from $12 \%$ in Oslo to $23 \%$ in Copenhagen. Non-road transport is an important contributing sector (14 to $21 \%$ ) and its contri- butions in Oslo and Helsinki are higher than on-road transport. As noted by Kukkonen et al. (2016), emissions from shipping and harbors are an important non-road transport influence for Oslo and Helsinki. Biogenic emissions are also important contributors in all four cities, with contributions ranging from 12 to $20 \%$. The energy sector contributes 12 to $13 \%$ in Helsinki, Stockholm, and Copenhagen, but its contribution to H1MDA8 ozone in Oslo is slightly less than $5 \%$.

Figure 8 shows the source apportionment results for the 16 cities across the distribution of summertime MDA8 ozone values. Results are shown for the upper and lower quartiles, the median, and the 90th percentile value for each city. Boundary conditions are clearly the primary contributors across the MDA8 ozone distribution at a majority of the 
Table 6. Sectors contributing $5 \%$ or more to summertime H1MDA8 ozone concentrations. Sector contributions in percentages are shown in parentheses.

\begin{tabular}{|c|c|c|c|c|c|c|}
\hline \multirow{2}{*}{$\begin{array}{l}\text { City (ppb) } \\
\text { Barcelona (58) }\end{array}$} & \multicolumn{6}{|c|}{ Sector* contributions (\%) } \\
\hline & $\mathrm{BC}(28)$ & SNAP 7 (21) & SNAP 8 (18) & Biogenic (15) & SNAP 34 (7) & SNAP 1 (5) \\
\hline Lisbon (61) & $\mathrm{BC}(34)$ & SNAP 7 (20) & Biogenic (19) & SNAP 8 (11) & SNAP 34 (6) & SNAP 1 (6) \\
\hline Athens (69) & $\mathrm{BC}(26)$ & SNAP 7 (24) & SNAP 8 (16) & Biogenic (15) & SNAP 1 (8) & SNAP 34 (6) \\
\hline Istanbul (73) & $\mathrm{BC}(26)$ & Biogenic (24) & SNAP 7 (15) & SNAP 8 (13) & SNAP 34 (9) & SNAP $1(8)$ \\
\hline Minsk (58) & $\mathrm{BC}(25)$ & Biogenic (23) & SNAP 7 (19) & SNAP 1 (15) & SNAP 8 (10) & - \\
\hline Budapest (63) & SNAP 7 (35) & $\mathrm{BC}(29)$ & SNAP 1 (11) & Biogenic (10) & SNAP 8 (7) & SNAP 34 (5) \\
\hline Warsaw (66) & $\mathrm{BC}(28)$ & SNAP 7 (24) & SNAP 1 (17) & Biogenic (14) & SNAP 8 (7) & SNAP 34 (7) \\
\hline Kiev (70) & Biogenic (33) & $\mathrm{BC}(21)$ & SNAP 7 (18) & SNAP 8 (10) & SNAP 1 (9) & SNAP 34 (6) \\
\hline London (41) & $\mathrm{BC}(56)$ & SNAP 8 (12) & SNAP 7 (11) & Biogenic (8) & - & - \\
\hline Paris (44) & $\mathrm{BC}(59)$ & SNAP 7 (13) & Biogenic (10) & SNAP 8 (6) & SNAP 6 (6) & - \\
\hline Amsterdam (51) & BC (29) & Biogenic (21) & SNAP 7 (19) & SNAP 6 (10) & SNAP 8 (8) & SNAP 1 (6) \\
\hline Berlin (56) & $\mathrm{BC}(46)$ & SNAP 7 (17) & SNAP 1 (13) & Biogenic (11) & SNAP 8 (6) & - \\
\hline Copenhagen (44) & BC (29) & SNAP 7 (23) & SNAP 8 (14) & SNAP 1 (13) & Biogenic (12) & SNAP 34 (5) \\
\hline Oslo (50) & $\mathrm{BC}(41)$ & Biogenic (20) & SNAP 8 (14) & SNAP 7 (12) & - & - \\
\hline Helsinki (50) & $\mathrm{BC}(31)$ & SNAP $8(21)$ & SNAP 7 (17) & SNAP 1 (13) & Biogenic (13) & - \\
\hline Stockholm (57) & SNAP 7 (24) & $\mathrm{BC}(21)$ & SNAP 8 (18) & Biogenic (18) & SNAP 1 (12) & - \\
\hline
\end{tabular}

* See Table 1 for anthropogenic (SNAP) sector descriptions.

Table 7. Sectors contributing $5 \%$ or more to summertime monthly mean $\mathrm{PM}_{2.5}$ concentrations. Sector contributions in percentages are shown in parentheses.

\begin{tabular}{llllllll}
\hline City $\left(\mu \mathrm{g} \mathrm{m}^{-3}\right)$ & \multicolumn{7}{c}{ Sector contributions (\%) } \\
\hline Lisbon (11) & BC (45) & SNAP 8 (18) & SOA (15) & SNAP 34 (6) & SNAP 7 (5) & - & - \\
Barcelona (12) & BC (40) & SNAP 8 (19) & SOA (11) & SNAP 7 (10) & SNAP 34 (5) & - & - \\
Athens (16) & BC (38) & SNAP 1 (15) & SNAP 8 (10) & SOA (9) & SNAP 10 (8) & SNAP 7 (7) & SNAP 34 (6) \\
Istanbul (17) & BC (49) & SNAP 34 (11) & SOA (8) & SNAP 1 (8) & SNAP 10 (7) & SNAP 8 (6) & - \\
Budapest (10) & SNAP 1 (23) & BC (23) & SNAP 10 (13) & SOA (13) & SNAP 34 (9) & SNAP 7 (8) & SNAP 8 (5) \\
Warsaw (13) & SNAP 1 (24) & BC (21) & SOA (13) & SNAP 10 (12) & SNAP 7 (10) & SNAP 8 (8) & SNAP 34 (8) \\
Minsk (13) & BC (27) & SOA (18) & SNAP 10 (14) & SNAP 1 (14) & SNAP 7 (8) & SNAP 8 (7) & SNAP 34 (7) \\
Kiev (13) & BC (37) & SOA (17) & SNAP 10 (12) & SNAP 1 (9) & SNAP 8 (9) & SNAP 34 (6) & - \\
Berlin (8) & SOA (19) & SNAP 1 (15) & SNAP 8 (14) & BC (14) & SNAP 7 (12) & SNAP 34 (10) & SNAP 10 (8) \\
London (10) & SOA (32) & SNAP 8 (23) & SNAP 7 (13) & BC (12) & SNAP 1 (7) & SNAP 34 (5) & - \\
Paris (11) & SOA (18) & SNAP 8 (16) & SNAP 10 (14) & BC (14) & SNAP 7 (13) & SNAP 34 (8) & SNAP 1 (8) \\
Amsterdam (13) & SNAP 8 (28) & SOA (23) & SNAP 7 (13) & SNAP 1 (9) & BC (9) & SNAP 34 (6) & SNAP 10 (6) \\
Oslo (8) & SNAP 8 (25) & SOA (25) & SNAP 2 (11) & BC (10) & SNAP 7 (9) & SNAP 1 (7) & SNAP 34 (6) \\
Stockholm (8) & SOA (31) & SNAP 8 (15) & BC (15) & SNAP 1 (12) & SNAP 7 (10) & SNAP 34 (7) & - \\
Helsinki (8) & SOA (31) & BC (15) & SNAP 8 (15) & SNAP 7 (13) & SNAP 1 (10) & SNAP 34 (5) & - \\
Copenhagen (11) & SNAP 8 (26) & SOA (23) & BC (11) & SNAP 7 (10) & SNAP 1 (10) & SNAP 10 (7) & SNAP 34 (6) \\
\hline
\end{tabular}

* See Table 1 for anthropogenic (SNAP) sector descriptions.

cities selected for analysis, and particularly in London and Paris. Except for Budapest, boundary conditions are the primary contributors at all cities at the low end of the distribution. Road transport contributions are important in many cities, particularly Budapest and Athens (across the distribution), Warsaw, Lisbon, Minsk, Kiev, and Berlin (at the higher end of the distribution). Non-road transport contributions are important in the Mediterranean cities and in the Nordic cities, particularly at the higher end of the distribution. Biogenic emissions are the highest contributors in Kiev at the high end of the distribution and are also important in the Mediterranean cities and most of the other selected cities. Contributions from the energy sector are important in the central and eastern European countries, particularly Warsaw.

As noted previously, boundary condition contributions also include the contribution of initial conditions, which are expected to decrease over the 1-week spin-up period and the subsequent month-long simulation period. At the end of the 1-week spin-up period (i.e., on 1 August), initial condition contributions to summertime H1MDA8 ozone were es- 
Table 8. Sectors contributing $5 \%$ or more to wintertime monthly mean $\mathrm{PM}_{2.5}$ concentrations. Sector contributions in percentages are shown in parentheses.

\begin{tabular}{|c|c|c|c|c|c|c|c|c|}
\hline \multirow{2}{*}{$\begin{array}{l}\text { City }\left(\mu \mathrm{g} \mathrm{m}^{-3}\right) \\
\text { Lisbon (13) }\end{array}$} & \multicolumn{8}{|c|}{ Sector* contributions $(\%)$} \\
\hline & SOA (47) & SNAP 2 (15) & SNAP 8 (13) & SNAP 7 (7) & SNAP 34 (6) & - & - & - \\
\hline Barcelona (13) & SNAP 8 (21) & SOA (18) & SNAP 7 (18) & SNAP 2 (17) & SNAP 10 (7) & SNAP 1 (7) & SNAP 34 (7) & - \\
\hline Athens (15) & SNAP 2 (20) & SNAP 8 (17) & SOA (13) & $\mathrm{BC}(12)$ & Dust (10) & SNAP 7 (10) & SNAP 1 (9) & - \\
\hline Istanbul (26) & SNAP $2(25)$ & SNAP 7 (11) & $\mathrm{BC}(11)$ & SNAP 34 (11) & SNAP 1 (10) & SNAP 8 (10) & SNAP 10 (9) & SOA (6) \\
\hline Budapest (30) & SNAP 2 (29) & SNAP 7 (18) & SNAP 1 (17) & SNAP $10(15)$ & SNAP 8 (7) & SNAP 34 (7) & - & - \\
\hline Minsk (30) & SNAP 2 (33) & SNAP 10 (16) & SNAP 1 (13) & SNAP 7 (12) & SNAP 8 (10) & SNAP 34 (7) & - & - \\
\hline Kiev (31) & SNAP 2 (37) & SNAP 10 (12) & SNAP 1 (11) & SNAP 8 (10) & SNAP 7 (10) & SNAP 34 (9) & - & - \\
\hline Warsaw (38) & SNAP 2 (34) & SNAP 7 (17) & SNAP 10 (16) & SNAP 1 (12) & SNAP 8 (7) & SNAP 34 (6) & - & - \\
\hline London (21) & SNAP 8 (23) & SOA (23) & SNAP 7 (19) & SNAP 2 (11) & SNAP $10(7)$ & SNAP 1 (6) & - & - \\
\hline Paris (25) & SNAP 2 (30) & SOA (16) & SNAP 7 (16) & SNAP 8 (13) & SNAP 10 (8) & SNAP 1 (6) & SNAP 34 (6) & - \\
\hline Amsterdam (26) & SNAP 7 (19) & SNAP 8 (18) & SNAP 2 (16) & SNAP 10 (13) & SOA (12) & SNAP 1 (10) & SNAP 34 (7) & - \\
\hline Berlin (32) & SNAP 2 (24) & SNAP 7 (18) & SNAP $10(15)$ & SNAP 1 (12) & SNAP 8 (11) & SNAP 34 (7) & SOA (6) & - \\
\hline Stockholm (17) & SNAP 7 (22) & SNAP 2 (19) & SNAP 8 (16) & SOA (14) & SNAP 1 (10) & SNAP $10(7)$ & SNAP 34 (6) & - \\
\hline Oslo (19) & SNAP 2 (47) & SNAP 8 (16) & SNAP 7 (11) & SOA (7) & SNAP 1 (6) & SNAP 10 (5) & - & - \\
\hline Helsinki (21) & SNAP 2 (33) & SNAP 7 (18) & SNAP 8 (14) & SNAP 1 (9) & SOA (9) & SNAP $10(7)$ & SNAP 34 (5) & - \\
\hline Copenhagen (24) & SNAP $2(20)$ & SNAP 8 (19) & SNAP 7 (14) & SNAP $10(12)$ & SNAP 1 (12) & SOA (11) & SNAP 34 (6) & - \\
\hline
\end{tabular}

* See Table 1 for anthropogenic (SNAP) sector descriptions.

timated for six cities (Paris, Lisbon, Warsaw, Athens, Oslo, and London) and ranged from 5\% at Lisbon (H1MDA8 ozone of $38 \mathrm{ppb}$ ) to $54 \%$ at Oslo (H1MDA8 ozone of $22 \mathrm{ppb})$.

\subsection{PM $_{2.5}$ source apportionment - summer}

The European standard for fine PM is an annual average concentration of $25 \mu \mathrm{g} \mathrm{m}^{-3}$. Since we obtained source attribution for only 2 months, our discussion of the $\mathrm{PM}_{2.5}$ source attribution focuses on the summer and winter monthly average concentrations. The spatial patterns of monthly mean $\mathrm{PM}_{2.5}$ concentrations for August 2010 across the modeling domain are shown in Fig. C2 in Supplement C. The highest $\mathrm{PM}_{2.5}$ concentrations are near the southern and southeastern boundaries of the domain and in the Mediterranean countries. These high concentrations are likely due to the transport of Saharan dust from northern Africa from the boundary conditions as well as from the dust emissions within the modeling domain (which includes part of the Sahara) estimated by the GOCART model in WRF-Chem. While most of the Saharan dust is coarse, a significant fraction is fine mode (e.g., Zauli Sajani et al., 2012; Fig. 7 in Pio et al., 2014). Removing the dust component from the calculated total $\mathrm{PM}_{2.5}$ concentrations reduces the highest concentrations along the southern boundary by a factor of 2 .

Table 7 shows the source attribution results for monthly mean $\mathrm{PM}_{2.5}$ concentrations in August 2010. In the Mediterranean cities of Lisbon, Barcelona, Athens, and Istanbul, boundary conditions are the largest contributors to mean $\mathrm{Au}$ gust $\mathrm{PM}_{2.5}$ concentrations, with contributions ranging from 38 to $49 \%$. Non-road transport and SOA are the second and third largest contributors in Lisbon and Barcelona. In Athens, the energy and non-road transport sectors are the second and third largest contributors, while in Istanbul the industry sector is the second largest contributor and SOA and the energy sector are the third largest contributors. Road transport contributions are less than $5 \%$ in Istanbul and less than $10 \%$ in Lisbon and Athens. The highest on-road transport contribution to the selected Mediterranean cities is $10 \%$ in Barcelona. The industry sector contributions in all four Mediterranean cities are $5 \%$ or more, while the SOA contributions in the four cities are $8 \%$ or more. The agriculture sector (SNAP 10) contribution to August 2010 mean $\mathrm{PM}_{2.5}$ concentrations is 7 to $8 \%$ in Athens and Istanbul and less than $5 \%$ in the other two cities.

Boundary conditions are important contributors to monthly average $\mathrm{PM}_{2.5}$ concentrations at cities in central and eastern Europe as well, as shown in Table 7, but the relative $\mathrm{BC}$ contributions in these regions are lower than those in southern Europe. BC is the largest contributor in Minsk and Kiev, while the energy sector is the largest contributor in Budapest and Warsaw. The dominant component (>60\%) of the boundary condition contribution in Minsk and Kiev is primary fine crustal material. The energy sector contributions range from $9 \%$ in Kiev to $24 \%$ in Warsaw. SOA is also an important contributor in all four cities and is the second largest contributor in Minsk (18\%) and Kiev (17\%). The agriculture sector also has a large contribution in all four cities $(12 \%$ to $14 \%)$, suggesting that ammonia emissions from agricultural activity leads to formation of particulate nitrate. The industry sector contributes from 6 to $9 \%$ of $\mathrm{PM}_{2.5}$ concentrations in the four cities. Road transport contributions are $8 \%$ in Budapest and Minsk and $10 \%$ in Warsaw, but less than $5 \%$ in Kiev. Non-road transport contributions are more than $5 \%$ in the four cities, but less than $10 \%$.

Boundary conditions are not large contributors to the $\mathrm{Au}$ gust monthly average $\mathrm{PM}_{2.5}$ concentrations in any of the four 

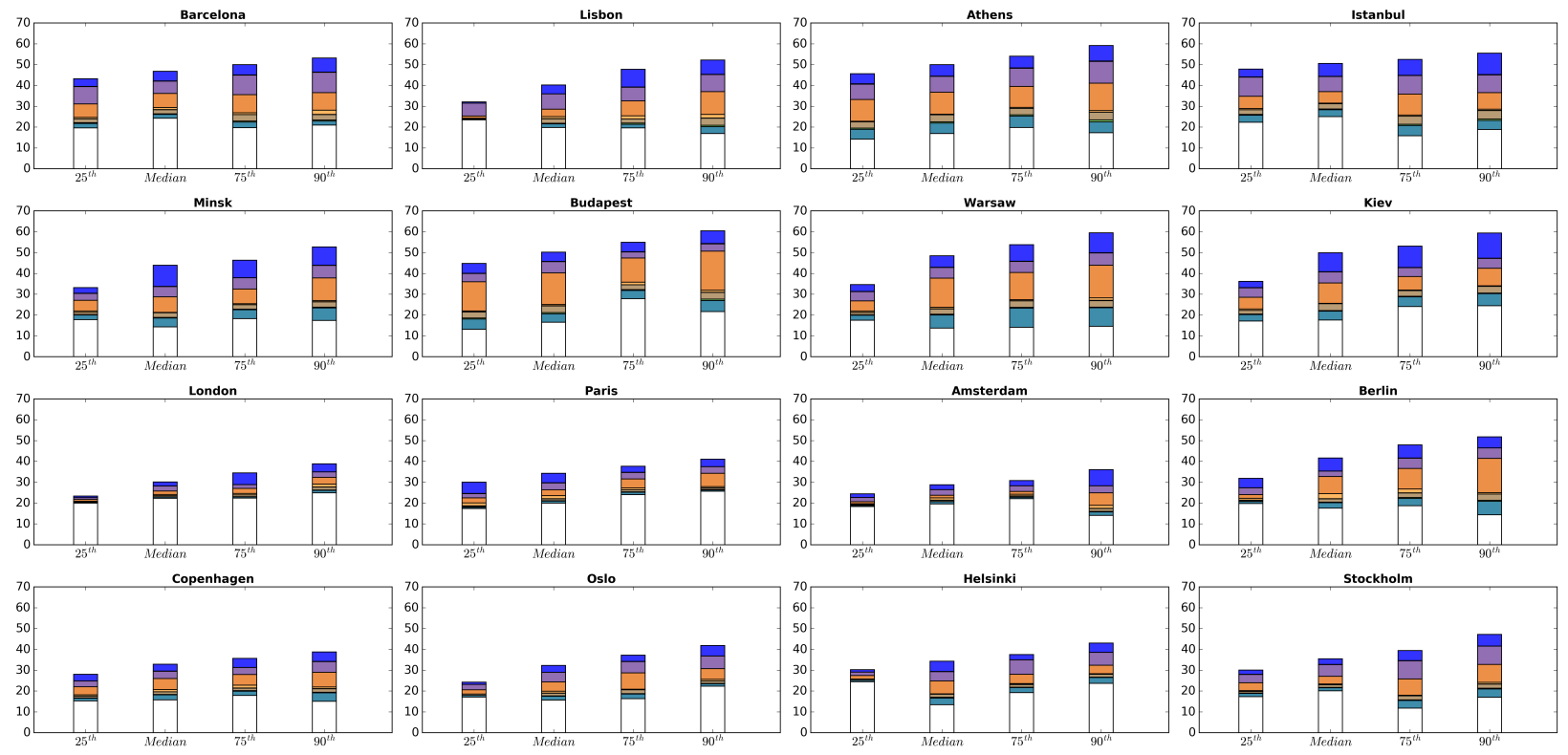

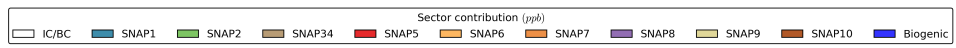

Figure 8. Source attribution results for the distribution of summertime MDA8 ozone concentrations for the 16 cities.

western European cities. Boundary condition contributions range from $9 \%$ in Amsterdam to $14 \%$ in Paris and Berlin. SOA is the largest contributor in London, Paris, and Berlin, while non-road transport is the largest contributor $(28 \%)$ in Amsterdam. Non-road transport is an important contributor in the other three cities as well, with contributions ranging from $14 \%$ in Berlin to $23 \%$ in London. The energy sector has a $15 \%$ contribution in Berlin, but less than $10 \%$ in the other three cities. Agriculture has a large contribution $(14 \%)$ in Paris, but lower contributions in Berlin (8\%) and Amsterdam (6\%). Agriculture contributions to the mean August $2010 \mathrm{PM}_{2.5}$ concentrations in London are less than $5 \%$. Road transport is an important but not major contributor $(12$ to $13 \%$ ) in any of the four western European cities.

The source attribution results for the four cities in the Nordic countries show the decreasing influence of boundary conditions in the northern portion of the modeling domain. Boundary condition contributions are not as large as for some of the cities to the south and they range from 10 to $15 \%$. SOA and non-road transport are the highest contributors in Oslo and contribute about $25 \%$ each. SOA is the largest contributor (about $31 \%$ ) in Helsinki and Stockholm, while non-road transport is the largest contributor in Copenhagen. Non-road transport is the second highest contributor in Stockholm. Energy sector emissions contribute from 7 to $12 \%$ to monthly mean $\mathrm{PM}_{2.5}$ concentrations, while the on-road transport sector contributes 9 to $13 \%$. Residential combustion (SNAP 2) contributes $11 \%$ in Oslo but less than $5 \%$ in the other three Nordic cities.
Figure 9 shows the source apportionment results for the 16 cities across the distribution of daily average summertime $\mathrm{PM}_{2.5}$ concentrations. In the Mediterranean cities, boundary conditions are more important at the high end of the distribution, suggesting that the higher $\mathrm{PM}_{2.5}$ concentrations in these cities are often associated with transport from outside of the domain. Non-road transport is an important contributor across the distribution in Barcelona and Lisbon, but it is less important in Athens and Istanbul. SOA contributions are important in all cities, particularly Athens.

Boundary conditions are important contributors in Minsk and Kiev, particularly at the high end of the distribution and to the 90th percentile daily average $\mathrm{PM}_{2.5}$ in Warsaw. The energy sector is a large contributor across the distribution in Warsaw and at the 90th percentile value in Budapest. In Minsk, the energy sector is more important at the low end of the distribution. SOA contributions are important at the high end of the distribution in Minsk and Warsaw.

Boundary condition contributions to summertime $\mathrm{PM}_{2.5}$ are less important at the selected cities in western Europe. Non-road transport and SOA are the largest contributors in London and Amsterdam, particularly at the high end of the distribution. In Berlin, SOA contributions are important across the $\mathrm{PM}_{2.5}$ distribution, while non-road transport contributions are important at the 75th and 90th percentile values. The contributions of boundary conditions are small to negligible and SOA contributions are high in all four selected Nordic cities. Non-road transport contributions are important in Copenhagen and Oslo, particularly at the high ends of the distribution. The energy sector is the highest contributor at 

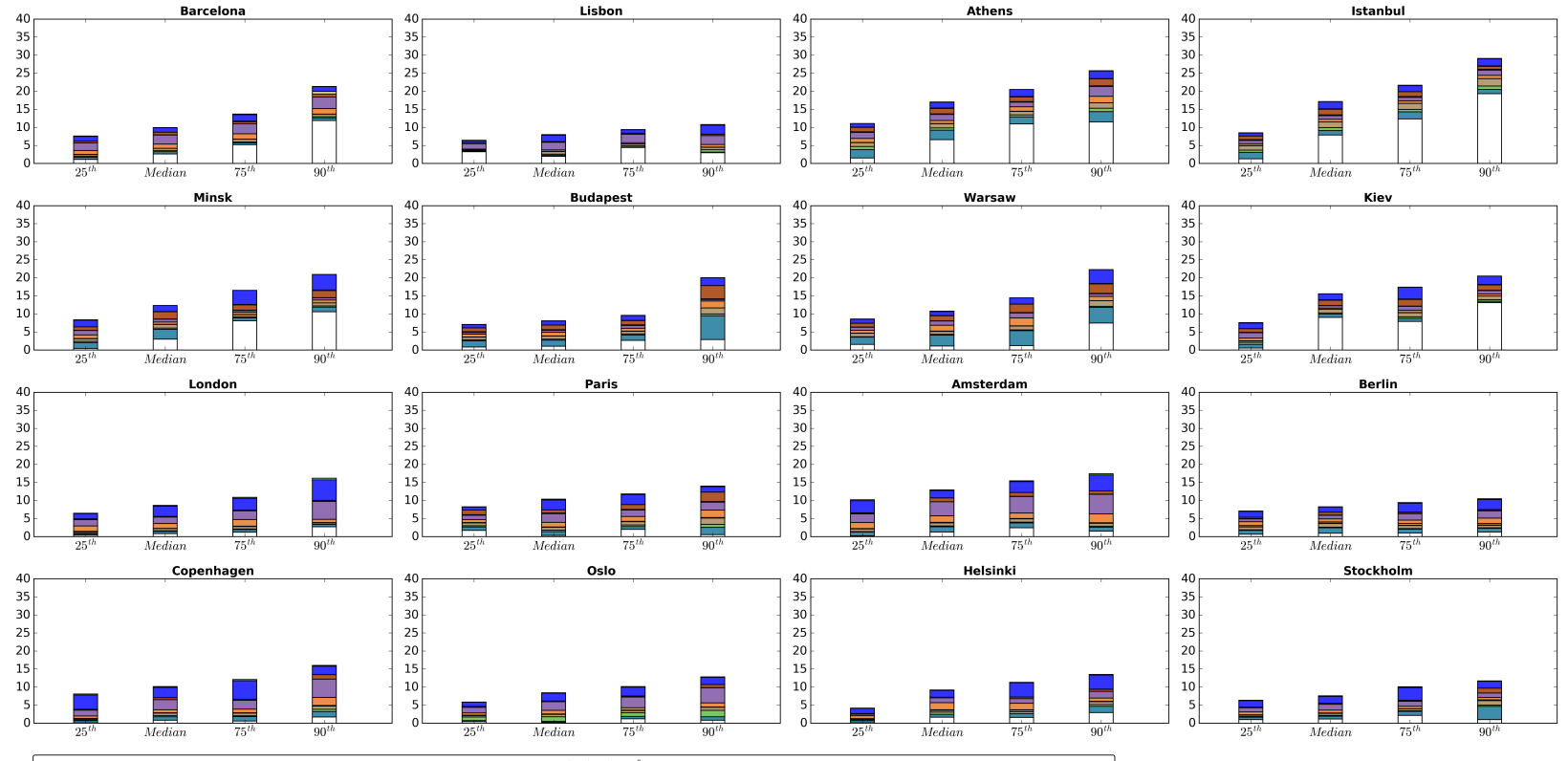

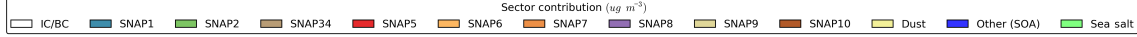

Figure 9. Source attribution results for the distribution of summertime daily $\mathrm{PM}_{2.5}$ concentrations for the 16 cities.

the 90th percentile value in Stockholm, but is less important at the lower quantiles. Energy sector contributions are small but non-negligible in Helsinki.

Initial condition contributions are also included in the boundary condition contributions shown in Table 7 and Fig. 9. At the end of the 1-week spin-up period on $1 \mathrm{Au}-$ gust, estimated initial condition contributions to $24 \mathrm{~h}$ average summertime $\mathrm{PM}_{2.5}$ concentrations at six cities ranged from $6 \%$ at Warsaw (24 h average $\mathrm{PM}_{2.5}$ of $\left.14 \mu \mathrm{g} \mathrm{m}^{-3}\right)$ to $17 \%$ at Oslo ( $24 \mathrm{~h}$ average $\mathrm{PM}_{2.5}$ of $13 \mu \mathrm{g} \mathrm{m}^{-3}$ ). These initial condition contributions are expected to be smaller for the monthly average $\mathrm{PM}_{2.5}$ concentrations shown in Table 7.

\section{3 $\quad$ PM $_{2.5}$ source apportionment - winter}

Figure C3 in Supplement C shows the spatial distribution of monthly mean $\mathrm{PM}_{2.5}$ concentrations for February 2010 across the modeling domain. The highest $\mathrm{PM}_{2.5}$ concentrations are again along the southern boundary of the modeling domain, but the influence of boundary conditions further inside the domain is lower than for the summertime $\mathrm{PM}_{2.5}$ concentrations, as shown in Table 8. High $\mathrm{PM}_{2.5}$ concentrations are also predicted over Poland and we see from Table 8 that, from the 16 cities selected for the analysis, the highest $\mathrm{PM}_{2.5}$ concentration $\left(38 \mu \mathrm{g} \mathrm{m}^{-3}\right)$ is in Warsaw.

As mentioned above, Table 8 shows that boundary condition contributions to wintertime $\mathrm{PM}_{2.5}$ concentrations in cities along the Mediterranean coastline are much lower than summertime contributions, particularly at cities in the west, such as Lisbon and Barcelona, where BC contributions are less than $5 \%$. BC contributions are slightly higher than $10 \%$ in the eastern Mediterranean cities (Athens and Istanbul). There are some variabilities in source contributions among the four Mediterranean cities. In Lisbon, SOA is the single largest contributor, explaining nearly $50 \%$ of the winter average $\mathrm{PM}_{2.5}$. Residential combustion is the next largest contributor at $15 \%$, followed by non-road transport at $13 \%$. Nonroad transport is the largest contributor (21\%) in Barcelona, followed by SOA, on-road transport, and residential combustion with comparable contributions (17 to $18 \%$ ). Residential combustion is the largest contributor in both Athens $(20 \%)$ and Istanbul $(25 \%)$. Non-road transport is the next highest contributor in Athens, while on-road transport, industry, and boundary conditions are the second highest contributors $(11 \%)$ in Istanbul. Energy sector contributions are more important in the eastern Mediterranean cities (9 to 10\%) than in the western cities (less than $5 \%$ in Lisbon and $7 \%$ in Barcelona). Road transport contributions in Lisbon and Athens are $10 \%$ or less. Dust emissions within the modeling domain contribute $10 \%$ of the $\mathrm{PM}_{2.5}$ in Athens.

At the four selected cities in central and eastern Europe, residential combustion is the single largest contributor to wintertime $\mathrm{PM}_{2.5}$, with contributions ranging from 29 to $38 \%$. Boundary condition contributions are less than $5 \%$ in all four cities. Road transport and the energy sector are the second highest contributors in Budapest (17 to $18 \%$ ), followed by agriculture at $15 \%$. In Kiev, agriculture and the energy sector are the second highest contributors (11 to $12 \%$ ), followed by on-road and non-road transport at $10 \%$ and industry at $9 \%$. Agriculture is the second highest contributor in Minsk (16\%), followed by the energy sector and on-road transport (12 to $13 \%$ ). In Warsaw, the second highest contri- 
butions to wintertime $\mathrm{PM}_{2.5}$ are from on-road transport and agriculture (16 to $17 \%$ ), while the energy sector contributes $12 \%$. Non-road and industry contributions in Warsaw are comparable and less than $10 \%$.

There is significant variability in the source-sector $\mathrm{PM}_{2.5}$ contributions among the cities in western Europe. In London, non-road transport and SOA are the largest contributors $(23 \%)$, followed by on-road transport $(19 \%)$ and residential combustion (11\%). Nearly $90 \%$ of the SOA concentration in London is from biogenic precursors. Note that the source attribution simulation conducted in this study only considers source categories and does not distinguish among source regions. Thus, the SOA concentration in London could be of local origin or transported. The main contributors to the biogenic SOA concentrations in London were oxidation products of monoterpenes (46\%) and sesquiterpenes $(11 \%)$ as well as oligomerization of oxidized compounds (27\%). CAMx includes four pathways for monoterpene oxidation (oxidation by $\mathrm{OH}, \mathrm{O}_{3}, \mathrm{NO}_{3}$, or atomic oxygen) and three pathways $\left(\mathrm{OH}, \mathrm{O}_{3}, \mathrm{NO}_{3}\right)$ for sesquiterpenes. The importance of wintertime SOA in a number of different European countries is discussed in Aksoyoglu et al. (2011) and Crippa et al. (2013).

The contribution from agriculture and the energy sector to wintertime $\mathrm{PM}_{2.5}$ in London is about $7 \%$. In Amsterdam, on-road and non-transport are the largest contributors (18 to $19 \%)$, residential combustion ranks second (16\%), and agriculture and SOA contribute 12 to $13 \%$. The energy sector contributes $10 \%$ of wintertime $\mathrm{PM}_{2.5}$ in Amsterdam, while the industry sector contributes $7 \%$. In both Paris and Berlin, residential combustion is the largest contributor $(30 \%$ and $24 \%$, respectively). However, there are differences in the contributions of the other source sectors in these two cities. SOA and on-road transport contributions rank second in Paris at about $16 \%$, followed by non-road transport at $13 \%$, and 6 to $8 \%$ contribution from agriculture and the energy and industry sectors. In Berlin, on-road transport also ranks second but the contribution of SOA is only about $6 \%$. Agriculture $(15 \%)$, the energy sector (12\%), non-road transport (11\%), and industry $(7 \%)$ are also significant contributors to wintertime $\mathrm{PM}_{2.5}$ in Berlin.

Table 8 shows that, for all four cities in the Nordic countries, the contribution of boundary conditions is less than $5 \%$. The largest contributors in Oslo and Helsinki are residential combustion sources (47 and 33\%, respectively). The non-road and on-road transport sectors have significant contributions as well in these two cities (16 and $11 \%$ in Oslo, respectively, and 14 and $18 \%$ in Helsinki, respectively). SOA, the energy sector, and agriculture contribute 5 to $7 \%$ and 7 to $9 \%$ of the wintertime $\mathrm{PM}_{2.5}$ in Oslo and Helsinki, respectively. Residential combustion is also the largest contributor in Copenhagen (20\%) but it is followed closely by non-road transport (19\%). Road transport contributes $14 \%$ of the wintertime $\mathrm{PM}_{2.5}$ in Copenhagen, and agriculture, the energy sector, and SOA contribute about 11 to $12 \%$. Industry con- tributions in Copenhagen are about $6 \%$. Road transport is the largest contributor (22\%) in Stockholm but residential combustion and non-road transport are significant contributors as well, with contributions of about $19 \%$ and $16 \%$, respectively. SOA contributes $14 \%$ to wintertime $\mathrm{PM}_{2.5}$ in Stockholm, while the energy sector contributes about $10 \%$ and agriculture and industry contribute 6 to $7 \%$.

The source apportionment results for the 16 cities across the distribution of daily average wintertime $\mathrm{PM}_{2.5}$ concentrations are shown in Fig. 10. The contribution of boundary conditions is negligible to small across the distribution in all cities. SOA contributions in Lisbon dominate other sources at the 90th percentile value and are also important at the 50th and 75th percentile values. Residential combustion sources are important across the entire distribution in Istanbul and are the primary contributors at the 90th percentile value. The industry and agriculture sectors are also important contributors to the higher levels of wintertime $\mathrm{PM}_{2.5}$ in Istanbul. Residential combustion is an also important contributor in Athens and Barcelona, as is the non-road transport sector.

Residential combustion is the largest contributor across the distribution of wintertime $\mathrm{PM}_{2.5}$ concentrations in the four selected cities in central and western Europe. Other important sectors are agriculture and road transport. Non-road transport contributions are also important in Minsk, Warsaw, and Kiev, and the energy sector is important in Minsk, Budapest, and Warsaw. SOA contributions are large in three (London, Paris, Amsterdam) of the four cities in western Europe, particularly at the 90th percentile levels in London and Paris. The importance of wintertime SOA in Paris is consistent with the findings of Crippa et al. (2013). Residential combustion is an important source in Paris, Amsterdam, and Berlin and has non-negligible contributions in London as well. The energy sector is an important source in Berlin and, to a smaller extent, in Amsterdam. The road and non-road transport sectors are also important contributors in all four cities.

Residential combustion is an important source sector in the four Nordic cities, particularly Oslo, where contributions from this sector dominate over the entire distribution of wintertime $\mathrm{PM}_{2.5}$. SOA is the largest contributor at the 75th percentile level in Stockholm and is also an important contributor in Copenhagen. Both transport sectors are important in all four cities, with the non-road transport sector contribution being larger than the road transport contribution in Copenhagen and Oslo.

Initial condition contribution is also included in the boundary condition contribution shown in Table 8 and Fig. 10. At the end of the 1-week spin-up period on February 1, estimated initial condition contributions to $24 \mathrm{~h}$ average wintertime $\mathrm{PM}_{2.5}$ concentrations at six cities ranged from less than $1 \%$ at many cities to $5 \%$ at Oslo. These initial condition contributions are expected to be negligible for the monthly average $\mathrm{PM}_{2.5}$ concentrations shown in Table 8 . 

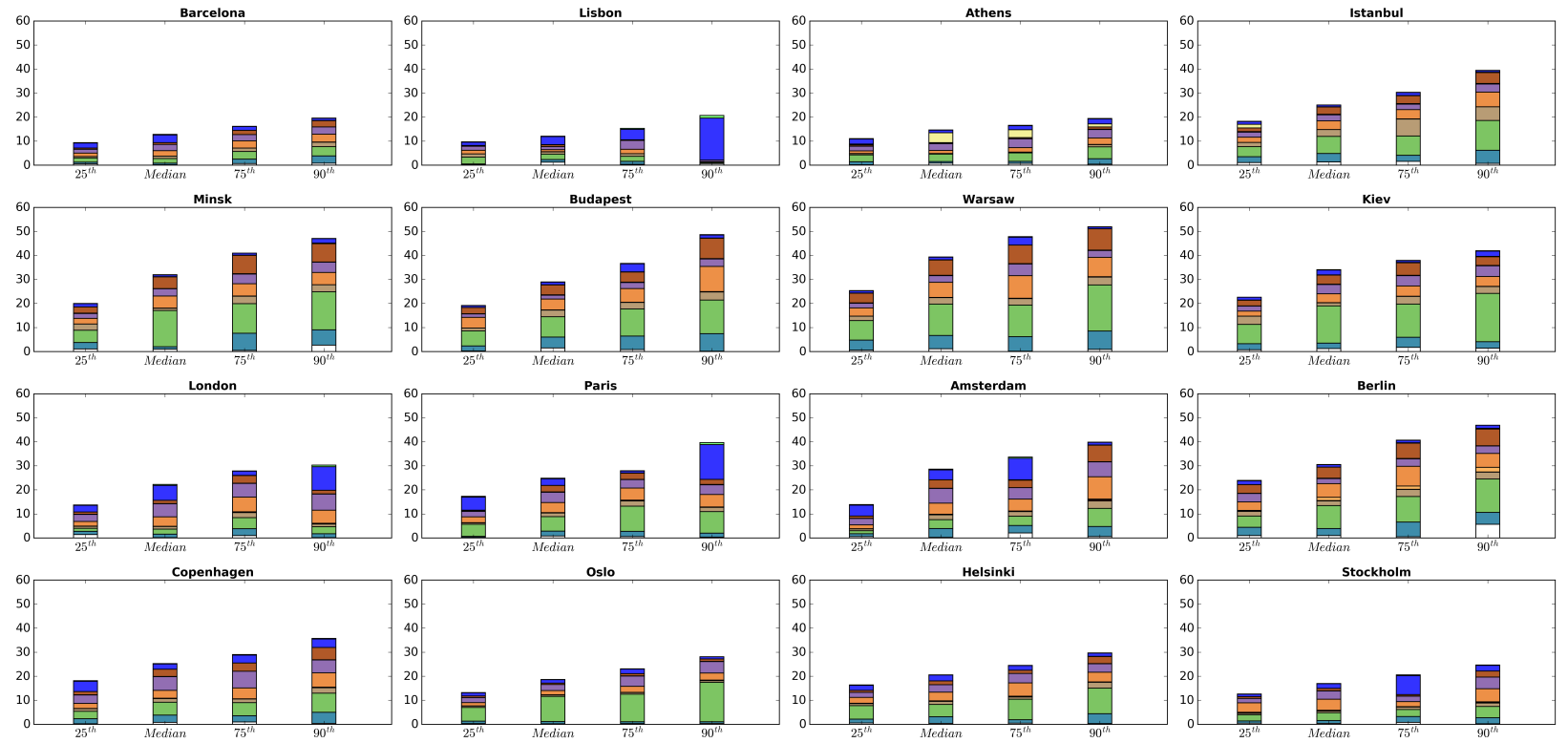

$\square$ ICIBC $\square$ SNAP1 $\square$ SNAP2 $\square$ SNAP34 $\square$ SNAP5 $\square$ SNAP6 Sector contribution (ug m mis)

Figure 10. Source attribution results for the distribution of wintertime daily $\mathrm{PM}_{2.5}$ concentrations for the 16 cities.

\section{Discussion}

The source attribution analysis results show that long-range transport of ozone from beyond Europe has a strong influence on summertime ozone in August 2010 over most of Europe. The background summertime ozone contribution, simulated by the boundary condition tracer in the OSAT simulation, is about 26 to $34 \%$ in southern Europe and 20 to $30 \%$ in central and eastern Europe. The boundary condition contributions in western Europe are larger, ranging from about 30 to $60 \%$. In the Nordic cities, BC contributions range from about $20 \%$ in Stockholm to $40 \%$ in Oslo. Wintertime ozone levels are below the EU standard and are dominated by boundary conditions ( $60 \%$ to over $90 \%$ ). The contribution of intercontinental transport (from North America and, to a smaller extent, from Asia) to ozone levels in Europe has been studied extensively through data analysis and modeling (e.g., Parrish et al., 1993; Wild and Akimoto, 2001; Lelieveld et al., 2002; Li et al., 2002; Naja et al., 2003; Trickl et al., 2003; Derwent et al., 2004, 2008; Auvray and Bey, 2005; Fehsenfeld et al., 2006; Guerova et al., 2006; Richards et al., 2013).

Summertime ozone contributions from biogenic emissions range from about 10 to $30 \%$. At the cities selected for the analysis, the largest biogenic contribution of $33 \%$ is in Kiev, while the lowest contribution of $8 \%$ is in London. For anthropogenic emission sectors, the combined transportation sector (on-road and non-road transport) contributions range from 30 to $40 \%$ in cities along the Mediterranean coastline, cities in central and eastern Europe, and cities in northern Europe. In western Europe, the combined transport sector has a contribution of 20 to $30 \%$. Contributions from the onroad transport sector are generally higher than those from the non-road transport sector, except for a few cities. The two transport sector contributions are comparable (within 3\%) in Barcelona, Istanbul, London, and Oslo. Non-road transport contributions are slightly higher than on-road contributions in Oslo and Helsinki. These results for summertime ozone concentrations are qualitatively consistent with those of Tagaris et al. (2015), who found that the on-road transport sector was the largest overall anthropogenic source sector contributing to July 2006 ozone concentrations in Europe, with non-road transport contributions ranking second. Pouliot et al. (2015) noted that emissions from on-road transport in Europe decreased from 2006 to 2009, while emissions from shipping increased. This explains some of the higher contributions of non-road transport to ozone concentrations in some cities that were calculated in our study.

The largest contributions of the energy sector were in central and eastern Europe (9 to $17 \%$ ) and in the Nordic cities (5 to $13 \%$ ). The power sector was also identified as a major contributor in Europe in the study by Brandt et al. (2013). Industry contributions to summertime ozone were important for the Mediterranean cities and cities in central and eastern Europe, with contributions ranging from 5 to $9 \%$.

For summertime ozone, the total contribution from sources that cannot be controlled within Europe (i.e., the boundary conditions and biogenic emissions) ranges from 39 to $69 \%$. The largest uncontrollable contributions are $69 \%$ in Paris and $64 \%$ in London, where the H1MDA8 city center ozone concentrations are 44 and $41 \mathrm{ppb}$, respectively, well below the $60 \mathrm{ppb}$ threshold. However, lower ozone levels are 
not necessarily associated with higher uncontrollable contributions, or vice versa. For example, the H1MDA8 ozone concentration in Copenhagen is $44 \mathrm{ppb}$, with anthropogenic sources contributing nearly $60 \%$. The highest H1MDA8 ozone concentrations among the selected cities are predicted in Istanbul (73 ppb) and Kiev (70 ppb), and the uncontrollable contributions are 50 and $54 \%$, respectively.

Boundary conditions constitute a large fraction (40 to $50 \%$ ) of the August 2010 average $\mathrm{PM}_{2.5}$ concentrations in the Mediterranean cities. The influence of boundary conditions decreases from southern to northern Europe. This decreasing south-to-north gradient suggests that the Mediterranean cities were influenced by long-range transport of dust emissions from northern Africa. These results are qualitatively consistent with numerous studies on the transport of Saharan dust and its contributions to PM levels in the Mediterranean Basin and other parts of Europe (e.g., Querol et al., 2001, 2004, 2009; Lyamani et al., 2005; Escudero et al., 2005, 2007a, b; Vanderstraeten et al., 2008; Marconi et al., 2014; Duchi et al., 2016). In contrast, there is an increasing south-to-north gradient in contributions of SOA (organic $\mathrm{PM}_{2.5}$ formed in the atmosphere from precursor VOC species) to summertime $\mathrm{PM}_{2.5}$ levels. Modeled SOA in Europe and North America is primarily associated with biogenic emissions (e.g., Sartelet et al., 2012). The contributions of SOA to summer PM range from 8 to $15 \%$ in the Mediterranean cities to 23 to $31 \%$ in the Nordic cities.

The anthropogenic source-sector contributions to summertime average $\mathrm{PM}_{2.5}$ vary with region. The important anthropogenic sectors in summer are the transport sector (both onroad and non-road), the energy sector, the industry sector, and agriculture. These sectors were also shown to be important for annual $\mathrm{PM}_{2.5}$ in the EMEP (2009) study. The contribution of other anthropogenic source sectors to the mean monthly $\mathrm{PM}_{2.5}$ is generally less than $10 \%$, with the exception of the solvent- and product-use sector, which has a contribution of over $10 \%$ in Amsterdam.

The source attribution results for wintertime $\mathrm{PM}_{2.5}$ are significantly different from the summertime results. The contributions of boundary conditions are generally less than $5 \%$, with the exception of the eastern Mediterranean cities of Athens and Istanbul, where the BC contributions are 12 and $11 \%$, respectively. SOA contributions are small (less than $10 \%$ ) to moderate (about $20 \%$ ) at most locations, except in Lisbon, where the SOA contribution is nearly $50 \%$.

The important anthropogenic sectors for wintertime $\mathrm{PM}_{2.5}$ are residential combustion, the combined transport sector (on-road and non-road), the energy sector, and agriculture, again qualitatively consistent with the EMEP (2009) results. Residential combustion contributions in winter are much higher than in summer and range from over $10 \%$ in London to nearly $50 \%$ in Oslo. Residential combustion is the largest contributor in 11 of the 16 cities studied in this work. Higher winter contributions from this sector are consistent with residential wood burning for heating in winter (e.g., De- nier van der Gon et al., 2015; Crilley et al., 2015), particularly in northern Europe (e.g., Krecl et al., 2008). As shown in Supplement Sect. A, primary $\mathrm{PM}_{2.5}$ emissions from residential combustion are a factor of 10 higher in winter than in summer.

Our model results are subject to limitations in model formulation and input data. Model performance evaluations presented here and by others, such as AQMEII Phase 3 contributors (see Solazzo et al., 2017), can suggest where modeling uncertainties exist and how they can influence source contributions. Important sources of uncertainty include anthropogenic emission inventories, biogenic emissions, dust emissions, sea salt emissions, boundary conditions, meteorology, and model formulation (e.g., SOA treatment). These uncertainties influence model performance as well as the source attribution analysis. A detailed uncertainty analysis using sensitivity studies would provide more insight on the linkage between model performance and the source attribution analysis. Although such an analysis was not conducted as part of this study, it is useful to discuss how uncertainties in inputs and model formulation can introduce uncertainties in the source attribution results. For example, when differences between modeled and observed concentrations are mostly driven by meteorology, we may expect, as a first approximation, that the relative source contributions are reasonable even though the absolute contributions are not well captured. In contrast, discrepancies related to emissions, boundary conditions, or model processes can be expected to bias both the absolute and relative contributions of specific sources. Uncertainties in boundary conditions, $\mathrm{NO}_{x}$ emissions, and biogenic emissions are important for both $\mathrm{O}_{3}$ and $\mathrm{PM}_{2.5}$. Uncertainties in SOA formation algorithms and dust emissions are important for $\mathrm{PM}_{2.5}$. For example, model underestimation for $\mathrm{PM}_{2.5}$ in summer could be due to underestimation of secondary organic aerosol caused by missing emission categories (e.g., intermediate VOC), biased inventories (e.g., uncertain biogenic emissions), and/or biased model SOA schemes, and these errors would influence the calculated source contributions. Quantifying source contributions can help assess when uncertainties are influential, keeping in mind that errors that underestimate impacts from a specific source may be less obvious than overestimation. The performance evaluation for summertime ozone showed overestimation at many cities, particularly in Budapest (fractional bias of $35 \%$ ). The source attribution analysis showed that boundary conditions had a significant contribution to summertime ozone in many cities, including a large contribution in Budapest (29\%), suggesting that boundary condition contributions may be overstated, leading to the overestimation bias.

The study presented here provides useful information on the contribution of sources that can be controlled (anthropogenic sources within Europe) versus uncontrollable sources, such as boundary conditions and biogenic emissions. This information can be used as part of the decision making process (along with economic, political, and soci- 
etal considerations) by policy makers in efforts to improve air quality.

Data availability. CAMx, the model used in the study, can be downloaded from http://www.camx.com/. The AirBase data used to evaluate model performance can be obtained from http://www.eea.europa.eu/data-and-maps/ data/airbase-the-european-air-quality-database- $8 . \quad$ The AQMEII modeling inputs used in the study are available to the AQME project participants at the AQME website: website:http://aqmeii.jrc.ec.europa.eu/.

\section{The Supplement related to this article is available online at doi:10.5194/acp-17-5643-2017-supplement.}

Competing interests. The authors declare that they have no conflict of interest.

Acknowledgements. This study was supported by the Coordinating Research Council Atmospheric Impacts Committee (CRC Project A-102). We gratefully acknowledge the contribution of various groups from the AQMEII Phase 3 project for the databases used in this work.

Edited by: B. R. D. Denby

Reviewed by: three anonymous referees

\section{References}

Aksoyoglu, S., Keller, J., Barmpadimos, I., Oderbolz, D., Lanz, V. A., Prévôt, A. S. H., and Baltensperger, U.: Aerosol modelling in Europe with a focus on Switzerland during summer and winter episodes, Atmos. Chem. Phys., 11, 7355-7373, doi:10.5194/acp11-7355-2011, 2011.

Aksoyoglu, S., Baltensperger, U., and Prévôt, A. S. H.: Contribution of ship emissions to the concentration and deposition of air pollutants in Europe, Atmos. Chem. Phys., 16, 1895-1906, doi:10.5194/acp-16-1895-2016, 2016.

Auvray, M. and Bey, I.: Long-range transport to Europe: Seasonal variations and implications for the European ozone budget, J. Geophys. Res., 110, D11303, doi:10.1029/2004JD005503, 2005.

Baker, K. R. and Kelly, J. T.: Single source impacts estimated with photochemical model source sensitivity and apportionment approaches, Atmos. Environ., 96, 266-274, 2014.

Belis, C. A., Cancelinha, J., Duane, M., Forcina, V., Pedroni, V., Passarella, R., Tanet, G., Douglas, K., Piazzalunga, A., Bolzacchini, E., Sangiorgi, G., Perrone, M. G., Ferrero, L., Fermo, P., and Larsen, B. R: Sources for PM air pollution in the Po Plain, Italy: I. Critical comparison of methods for estimating biomass burning contributions to benzo(a)pyrene, Atmos. Environ., 45, 7266-7275, 2011.

Belis, C. A., Karagulian, F., Larsen, B. R., and Hopke, P. K.: Critical review and meta-analysis of ambient particulate matter source apportionment using receptor models in Europe, Atmos. Environ., 69, 94-108, 2013.

Brandt, J., Silver, J. D., Christensen, J. H., Andersen, M. S., Bønløkke, J. H., Sigsgaard, T., Geels, C., Gross, A., Hansen, A. B., Hansen, K. M., Hedegaard, G. B., Kaas, E., and Frohn, L. M.: Contribution from the ten major emission sectors in Europe and Denmark to the health-cost externalities of air pollution using the EVA model system - an integrated modelling approach, Atmos. Chem. Phys., 13, 7725-7746, doi:10.5194/acp-13-77252013, 2013.

Burr, M. J. and Zhang, Y.: Source apportionment of fine particulate matter over the Eastern U.S. Part II: Source apportionment simulations using CAMx/PSAT and comparisons with CMAQ source sensitivity simulations, Atmos. Pollut. Res., 2, 318-336, 2011.

Byun, D. and Schere, K. L: Review of the governing equations, computational algorithms, and other components of the Models3 Community Multiscale Air Quality (CMAQ) modeling system, Appl. Mech. Rev., 59, 51-77, 2006.

Collet, S., Minoura, H., Kidokoro, T., Sonoda, Y., Kinugasa, Y., Karamchandani, P., Johnson, J., Shah, T., Jung, J., and DenBleyker, A.: Future year ozone source attribution modeling studies for the eastern and western United States, J. Air Waste Manage. Assoc., 64, 1174-1185, 2014.

Crilley, L. R., Bloss, W. J., Yin, J., Beddows, D. C. S., Harrison, R. M., Allan, J. D., Young, D. E., Flynn, M., Williams, P., Zotter, P., Prevot, A. S. H., Heal, M. R., Barlow, J. F., Halios, C. H., Lee, J. D., Szidat, S., and Mohr, C.: Sources and contributions of wood smoke during winter in London: assessing local and regional influences, Atmos. Chem. Phys., 15, 3149-3171, doi:10.5194/acp15-3149-2015, 2015

Crippa, M., DeCarlo, P. F., Slowik, J. G., Mohr, C., Heringa, M F., Chirico, R., Poulain, L., Freutel, F., Sciare, J., Cozic, J., Di Marco, C. F., Elsasser, M., Nicolas, J. B., Marchand, N., Abidi, E., Wiedensohler, A., Drewnick, F., Schneider, J., Borrmann, S., Nemitz, E., Zimmermann, R., Jaffrezo, J.-L., Prévt^^, A. S. H., and Baltensperger, U.: Wintertime aerosol chemical composition and source apportionment of the organic fraction in the metropolitan area of Paris, Atmos. Chem. Phys., 13, 961-981, doi:10.5194/acp-13-961-2013, 2013.

de Leeuw, G., Neele, F. P., Hill, M., Smith, M. H., and Vignati, E.: Production of sea spray aerosol in the surf zone, J. Geophys. Res., 105, 29397-29409, 2000.

Denier van der Gon, H. A. C., Bergström, R., Fountoukis, C., Johansson, C., Pandis, S. N., Simpson, D., and Visschedijk, A J. H.: Particulate emissions from residential wood combustion in Europe - revised estimates and an evaluation, Atmos. Chem. Phys., 15, 6503-6519, doi:10.5194/acp-15-6503-2015, 2015.

Derwent, R. G., Stevenson, D. S., Collins, W. J., and Johnson, C. E.: Intercontinental transport and the origins of the ozone observed at surface sites in Europe, Atmos. Environ., 38, 18911901, 2004.

Derwent, R. G., Stevenson, D. S., Doherty, R. M., Collins, W. J., Sanderson, M. G., Johnson, C. E., Cofala, J., Mechler, R., Amann, M., and Dentener, F. J.: The contribution from shipping emissions to air quality and acid deposition in Europe, Ambio, 34, 54-59, 2005.

Derwent, R. G., Stevenson, D. S., Doherty, R. M., Collins, W. J., and Sanderson, M. G.: How is surface ozone in Europe linked to 
Asian and North American $\mathrm{NO}_{x}$ emissions?, Atmos. Environ., 42, 7412-7422, 2008.

Duchi, R., Cristofanelli, P., Landi, T.C., Arduini, J., Bonafe, U., Bourcier, L., Busetto, M., Calzolari, F., Marinoni, A., Putero, D., and Bonasoni, P.: Long-term (2002-2012) investigation of Saharan dust transport events at Mt. Cimone GAW global station, Italy (2165 $\mathrm{m}$ a.s.1.), Elem. Sci. Anth., 4, 85, doi:10.12952/journal.elementa.000085, 2016.

Dunker, A. M., Yarwood, G., Ortmann, J. P., and Wilson, G. M.: Comparison of source apportionment and source sensitivity of ozone in a three-dimensional air quality model, Environ. Sci. Technol., 36, 2953-2964, 2002.

Escudero, M., Castillo, S., Querol, X., Avila, A., Alarcón, M., Viana, M. M., Alastuey, A., Cuevas, E., and Rodríguez, S.: Wet and dry African dust episodes over eastern Spain, J. Geophys. Res., 110, D18S08, doi:10.1029/2004JD004731, 2005.

Escudero, M., Querol, X., Ávila, A., and Cuevas, E.: Origin of the exceedances of the European daily PM limit value in regional background areas of Spain, Atmos. Environ., 41, 730-744, 2007a.

Escudero, M., Querol, X., Pey, J., Alastuey, A., Pérez, N., Ferreira, F., Alonso, S., Rodríguez, S., and Cuevas, E.: A methodology for the quantification of the net African dust load in air quality monitoring networks, Atmos. Environ., 41, 5516-5524, 2007b.

European Environment Agency (EEA): EMEP/EEA Air Pollutant Emission Inventory Guidebook, available at: http: //www.eea.europa.eu/publications/emep-eea-guidebook-2013/ at_download/file (last access: 20 March 2017), 2013.

European Monitoring and Evaluation Programme (EMEP): Transboundary Acidification, Eutrophication and Ground Level Ozone in Europe in 2007, available at: http://emep.int/publ/reports/ 2009/status_report_1_2009.pdf (last access: 20 March 2017), 2009.

Fehsenfeld, F. C., Ancellet, G., Bates, T. S., Goldstein, A. H., Hardesty, R. M., Honrath, R., Law, K. S., Lewis, A. C., Leaitch, R., McKeen, S., Meagher, J., Parrish, D. D., Pszenny, A. A. P., Russell, P. B., Schlager, H., Seinfeld, J., Talbot, R., and Zbinden, R.: International Consortium for Atmospheric Research on Transport and Transformation (ICARTT): North America to Europe Overview of the 2004 summer field study, J. Geophys. Res., 111, D23S01, doi:10.1029/2006jd007829, 2006.

Flemming, J., Huijnen, V., Arteta, J., Bechtold, P., Beljaars, A., Blechschmidt, A.-M., Diamantakis, M., Engelen, R. J., Gaudel, A., Inness, A., Jones, L., Josse, B., Katragkou, E., Marecal, V., Peuch, V.-H., Richter, A., Schultz, M. G., Stein, O., and Tsikerdekis, A.: Tropospheric chemistry in the Integrated Forecasting System of ECMWF, Geosci. Model Dev., 8, 975-1003, doi:10.5194/gmd-8-975-2015, 2015.

Galmarini, S., Rao, S. T., and Steyn, D. G.: Preface, Atmos. Environ., 53, 1-3, 2012.

Galmarini, S., Hogrefe, C., Brunner, D., Makar, P., and Baklanov, A.: Preface, Atmos. Environ., 115, 340-344, 2015.

Galmarini, S., Solazzo, E., Im, U., and Kioutsioukis, I.: AQMEII 1, 2 and 3: Direct and indirect benefits of community model evaluation exercises, in: Air Pollution Modeling and its Application XXIV, edited by: Steyn, G. D. and Chaumerliac, N., Springer International Publishing, Cham, Switzerland, 471-475, 2016.

Ginoux, P., Chin, M., Tegen, I., Prospero, J. M., Holben, B., Dubovik, O., and Lin, S.-J.: Sources and distributions of dust aerosols simulated with the GOCART model, J. Geophys. Res., 106, 20255-20273, 2001.

Ginoux, P., Prospero, J. M., Torres, O., and Chin, M.: Long-term simulation of global dust distribution with the GOCART model: correlation with North Atlantic Oscillation, Environ. Modell. Softw., 19, 113-128, 2004.

Giordano, L., Brunner, D., Flemming, J., Hogrefe, C., Im, U., Bianconi, R., Badia, A., Balzarini, A., Barò, R., Chemel, C., Curci, G., Forkel, R., Jiménez-Guerrero, P., Hirtl, M., Hodzic, A., Honzak, L., Jorba, O., Knote, C., Kuenen, J. J. P., Makar, P.A., MandersGroot, A., Neal, L., Pérez, J. L., Pirovano, G., Pouliot, G., San José, R., Savage, N., Schröder, W., Sokhi, R. S., Syrakov, D., Torian, A., Tuccella, P., Werhahn, J., Wolke, R., Yahya, K., Žabkar, R., Zhang, Y., and Galmarini, S.: Assessment of the MACC reanalysis and its influence as chemical boundary conditions for regional air quality modeling in AQMEII-2, Atmos. Environ., 115, 371-388, doi:10.1016/j.atmosenv.2015.02.034, 2015.

Gong, S. L.: A parameterization of sea-salt aerosol source function for sub- and super-micron particles, Global Biogeochem. Cy., 17, 1097, doi:10.1029/2003GB002079, 2003.

Guenther, A. B., Jiang, X., Heald, C. L., Sakulyanontvittaya, T., Duhl, T., Emmons, L. K., and Wang, X.: The Model of Emissions of Gases and Aerosols from Nature version 2.1 (MEGAN2.1): an extended and updated framework for modeling biogenic emissions, Geosci. Model Dev., 5, 1471-1492, doi:10.5194/gmd-51471-2012, 2012.

Guerova, G., Bey, I., Attié, J.-L., Martin, R. V., Cui, J., and Sprenger, M.: Impact of transatlantic transport episodes on summertime ozone in Europe, Atmos. Chem. Phys., 6, 205-2072, doi:10.5194/acp-6-2057-2006, 2006.

Inness, A., Baier, F., Benedetti, A., Bouarar, I., Chabrillat, S., Clark, H., Clerbaux, C., Coheur, P., Engelen, R. J., Errera, Q., Flemming, J., George, M., Granier, C., Hadji-Lazaro, J., Huijnen, V., Hurtmans, D., Jones, L., Kaiser, J. W., Kapsomenakis, J., Lefever, K., Leitão, J., Razinger, M., Richter, A., Schultz, M. G., Simmons, A. J., Suttie, M., Stein, O., Thépaut, J.-N., Thouret, V., Vrekoussis, M., Zerefos, C., and the MACC team: The MACC reanalysis: an $8 \mathrm{yr}$ data set of atmospheric composition, Atmos. Chem. Phys., 13, 4073-4109, doi:10.5194/acp-13-4073-2013, 2013.

Koo, B., Wilson, G. M., Morris, R. E., Dunker, A. M., and Yarwood, G.: Comparison of source apportionment and sensitivity analysis in a particulate matter air quality model, Environ. Sci. Technol., 43, 6669-6675, 2009.

Krecl, P., Hedberg Larsson, E., Ström, J., and Johansson, C.: Contribution of residential wood combustion and other sources to hourly winter aerosol in Northern Sweden determined by positive matrix factorization, Atmos. Chem. Phys., 8, 3639-3653, doi:10.5194/acp-8-3639-2008, 2008.

Kuenen, J. J. P., Visschedijk, A. J. H., Jozwicka, M., and Denier van der Gon, H. A. C.: TNO-MACC_II emission inventory; a multiyear (2003-2009) consistent high-resolution European emission inventory for air quality modelling, Atmos. Chem. Phys., 14, 10963-10976, doi:10.5194/acp-14-10963-2014, 2014.

Kukkonen, J., Karl, M., Keuken, M. P., Denier van der Gon, H. A. C., Denby, B. R., Singh, V., Douros, J., Manders, A., Samaras, Z., Moussiopoulos, N., Jonkers, S., Aarnio, M., Karppinen, A., Kangas, L., Lützenkirchen, S., Petäjä, T., Vouitsis, I., and Sokhi, R. S.: Modelling the dispersion of particle numbers in five European 
cities, Geosci. Model Dev., 9, 451-478, doi:10.5194/gmd-9-4512016, 2016.

Lelieveld, J., Berresheim, H., Borrmann, S., Crutzen, P. J., Dentener, F. J., Fischer, H., Feichter, J., Flatau, P. J., Heland, J., Holzinger, R., Korrmann, R., Lawrence, M. G., Levin, Z., Markowicz, K. M., Mihalopoulos, N., Minikin, A., Ramanathan, V., de Reus, M., Roelofs, G. J., Scheeren, H. A., Sciare, J., Schlager, H., Schultz, M., Siegmund, P., Steil, B., Stephanou, E. G., Stier, P., Traub, M., Warneke, C., Williams, J., and Ziereis, H.: Global air pollution crossroads over the Mediterranean, Science, 298, 794-799, 2002.

Li, Q., Jacob, D. J., Bey, I., Palmer, P. I., Duncan, B. N., Field, B. D., Martin, R. V., Fiore, A. M., Yantosca, R. M., Parrish, D.D., Simmonds, P. G., and Oltmans, S. J.: Transatlantic transport of pollution and its effects on surface ozone in Europe and North America, J. Geophys. Res., 107, ACH 4-1-ACH 4-21, doi:10.1029/2001JD001422, 2002.

Li, Y., Lau, A. K. H., Fung, J. C. H., Zheng, J. Y., Zhong, L. J., and Louie, P. K. K.: Ozone source apportionment (OSAT) to differentiate local regional and super-regional source contributions in the Pearl River Delta region, China, J. Geophys. Res., 117, 6259-6277, 2012.

Lyamani, H., Olmo, F. J., and Alados-Arboledas, L.: Saharan dust outbreak over southeastern Spain as detected by sun photometer, Atmos. Environ., 39, 7276-7284, 2005.

Marconi, M., Sferlazzo, D. M., Becagli, S., Bommarito, C., Calzolai, G., Chiari, M., di Sarra, A., Ghedini, C., Gómez-Amo, J. L., Lucarelli, F., Meloni, D., Monteleone, F., Nava, S., Pace, G., Piacentino, S., Rugi, F., Severi, M., Traversi, R., and Udisti, R.: Saharan dust aerosol over the central Mediterranean Sea: $\mathrm{PM}_{10}$ chemical composition and concentration versus optical columnar measurements, Atmos. Chem. Phys., 14, 2039-2054, doi:10.5194/acp-14-2039-2014, 2014

Naja, M., Akimoto, H., and Staehelin, J.: Ozone in background and photochemically aged air over central Europe: Analysis of longterm ozonesonde data from Hohenpeissenberg and Payerne, J. Geophys. Res., 108, 4063, doi:10.1029/2002JD002477, 2003.

Parrish, D. D., Holloway, J. S., Trainer, M., Murphy, P. C., Fehsenfeld, F. C., and Forbes, G. L.: Export of North American ozone pollution to the North Atlantic Ocean, Science, 259, 1436-1439, 1993.

Pio, C. A., Cardoso, J. G., Cerqueira, M. A., Calvo, A., Nunes, T. V., Alves, C. A., Custódio, D., Almeida, S. M., and Almeida-Silva, M.: Seasonal variability of aerosol concentration and size distribution in Cape Verde using a continuous aerosol optical spectrometer, Front. Environ. Sci., 2, 15, doi:10.3389/fenvs.2014.00015, 2014.

Pouliot, G., Denier van der Gon, H. A. C., Kuenen, J., Zhang, J., Moran, M. D., and Makar, P. A.: Analysis of the emission inventories and model-ready emission datasets of Europe and North America for phase 2 of the AQMEII project, Atmos. Environ., 115, 345-360, 2015.

Querol, X., Alastuey, A., Rodriguez, S., Plana, F., Ruiz, C. R., Cots, N., Massagué, G., and Puig, O.: $\mathrm{PM}_{10}$ and $\mathrm{PM}_{2.5}$ source apportionment in the Barcelona Metropolitan area, Catalonia, Spain, Atmos. Environ., 35, 6407-6419, 2001.

Querol, X., Alastuey, A., Ruiz, C. R., Artiñano, B., Hansson, H. C., Harrison, R. M., Buringh, E., ten Brink, H. M., Lutz, M., Bruckmann, P., Straehl, P., and Schneider, J.: Speciation and origin of
$\mathrm{PM}_{10}$ and $\mathrm{PM}_{2.5}$ in selected European cities, Atmos. Environ., 38, 6547-6555, 2004.

Querol, X., Pey, J., Pandolfi, M., Alastuey, A., Cusack, M., Pérez, N., Moreno, T., Viana, M., Mihalopoulos, N., Kallos, G., and Kleanthous, S.: African dust contributions to mean ambient $\mathrm{PM}_{10}$ mass-levels across the Mediterranean Basin, Atmos. Environ. 43, 4266-4277, 2009.

Ramboll Environ.: CAMx User's Guide Version 6.1. Environ International Corporation, Novato, CA, available at: http:// www.camx.com/files/camxusersguide_v6-10.pdf (last access: 20 March 2017), 2014.

Rao, S. T., Galmarini, S., and Puckett, K.: Air Quality Model Evaluation International Initiative (AQMEII): Advancing the state of the science in regional photochemical modeling and its applications, B. Am. Meteorol. Soc., 92, 23-30, 2011.

Reis, S., Simpson, D., Friedrich, R., Jonson, J. E., Unger, S., and Obermeier, A.: Road traffic emissions - predictions of future contributions to regional ozone levels in Europe, Atmos. Environ., 34, 4701-4710, 2000.

Richards, N. A. D., Arnold, S. R., Chipperfield, M. P., Miles, G., Rap, A., Siddans, R., Monks, S. A., and Hollaway, M. J.: The Mediterranean summertime ozone maximum: global emission sensitivities and radiative impacts, Atmos. Chem. Phys., 13, 2331-2345, doi:10.5194/acp-13-2331-2013, 2013.

Sartelet, K. N., Couvidat, F., Seigneur, C., and Roustan, Y.: Impact of biogenic emissions on air quality over Europe and North America, Atmos. Environ., 53, 131-141, 2012.

Skamarock, W. C., Klemp, J. B., Dudhia, J., Gill, D. O., Barker, D. M., Duda, M. G., Huang, X.-Y., Wang, W., and Powers, J. G.: A Description of the Advanced Research WRF version 3, National Center for Atmospheric Research Tech. Note, NCAR/TN475+STR, available at: http://www2.mmm.ucar.edu/wrf/users/ docs/arw_v3.pdf (last access: 20 March 2017), 2008.

Skyllakou, K., Murphy, B. N., Megaritis, A. G., Fountoukis, C., and Pandis, S. N.: Contributions of local and regional sources to fine PM in the megacity of Paris, Atmos. Chem. Phys., 14, 23432352, doi:10.5194/acp-14-2343-2014, 2014.

Solazzo, E. and Galmarini, S.: Error apportionment for atmospheric chemistry-transport models - a new approach to model evaluation, Atmos. Chem. Phys., 16, 6263-6283, doi:10.5194/acp-166263-2016, 2016.

Solazzo, E., Bianconi, R., Hogrefe, C., Curci, G., Tuccella, P., Alyuz, U., Balzarini, A., Baró, R., Bellasio, R., Bieser, J., Brandt, J., Christensen, J. H., Colette, A., Francis, X., Fraser, A., Vivanco, M. G., Jiménez-Guerrero, P., Im, U., Manders, A., Nopmongcol, U., Kitwiroon, N., Pirovano, G., Pozzoli, L., Prank, M., Sokhi, R. S., Unal, A., Yarwood, G., and Galmarini, S.: Evaluation and error apportionment of an ensemble of atmospheric chemistry transport modeling systems: multivariable temporal and spatial breakdown, Atmos. Chem. Phys., 17, 3001-3054, doi:10.5194/acp-17-3001-2017, 2017.

Tagaris, E., Sotiropoulou, R., Gounaris, N., Andronopoulos, S., and Vlachogiannis, D.: Effect of the Standard Nomenclature for Air Pollution (SNAP) categories on air quality over Europe, Atmosphere, 6, 1119, doi:10.3390/atmos6081119, 2015.

Terrenoire, E., Bessagnet, B., Rouïl, L., Tognet, F., Pirovano, G., Létinois, L., Beauchamp, M., Colette, A., Thunis, P., Amann, M., and Menut, L.: High-resolution air quality simulation over 
Europe with the chemistry transport model CHIMERE, Geosci. Model Dev., 8, 21-42, doi:10.5194/gmd-8-21-2015, 2015.

TRANSPHORM: Source Contributions of Transport Emissions for European Air Quality and Exposure, Deliverable 2.4.4, available at: http://www.transphorm.eu/Portals/51/Documents/Deliverables/New Deliverables/D2.4.4 Source contributions of transport emissions for European air quality and exposure.pdf (last access: 20 March 2017), 2014.

Trickl, T., Cooper, O.R., Eisele, H., James, P., Mücke, R., and Stohl, A.: Intercontinental transport and its influence on the ozone concentrations over central Europe: Three case studies, J. Geophys. Res., 108, 8530, doi:10.1029/2002JD002735, 2003.

Vanderstraeten, P., Lénelle, Y., Meurrens, A., Carati, D., Brenig, L., Delcloo, A., Offer, Z. Y., and Zaady, E.: Dust storm originate from Sahara covering Western Europe: A case study, Atmos. Environ., 42, 5489-5493, 2008.

Viana, M., Hammingh, P., Colette, A., Querol, X., Degraeuwe, B., Vlieger, I. D., and van Aardenne, J.: Impact of maritime transport emissions on coastal air quality in Europe, Atmos. Environ., 90, 96-105, 2014.

Wagstrom, K. M., Pandis, S. N., Yarwood, G., Wilson, G. M., and Morris, R. E.: Development and application of a computationally efficient particulate matter apportionment algorithm in a three-dimensional chemical transport model, Atmos. Environ., 42, 5650-5659, 2008.
Wang, X., Li, J., Zhang, Y., Xie, S., and Tang, X.: Ozone source attribution during a severe photochemical smog episode in Beijing, China. Sci. China Ser. B-Chem., 52, 1270-1280, 2009.

Wild, O. and Akimoto, H.: Intercontinental transport of ozone and its precursors in a three-dimensional global CTM, J. Geophys. Res., 106, 27729-27744, 2001.

Yarwood, G., Rao, S., Yocke, M., and Whitten, G.: Updates to the Carbon Bond Chemical Mechanism: CB05, Final Report to the US EPA, RT-0400675, available at: http://www.camx.com/publ/ pdfs/cb05_finalreport_120805.pdf (last access: 30 August 2016), 2005.

Yarwood, G., Morris, R. E., and Wilson, G. M.: Particulate matter Source Apportionment Technology (PSAT) in the CAMx photochemical grid model, in: Air Pollution Modeling and Its Application XVII, edited by: Borrego, C., and Norman, A.-L., Springer, New York, NY, USA, 478-492, 2007.

Zauli Sajani, S., Bonasoni, P., Cristofanelli, P., Marinoni, A., and Lauriola, P.: Only coarse particles from the Sahara?, Epidemiology, 23, 642-643, 2012.

Zhao, C., Liu, X., Leung, L. R., Johnson, B., McFarlane, S. A., Gustafson Jr., W. I., Fast, J. D., and Easter, R.: The spatial distribution of mineral dust and its shortwave radiative forcing over North Africa: modeling sensitivities to dust emissions and aerosol size treatments, Atmos. Chem. Phys., 10, 8821-8838, doi:10.5194/acp-10-8821-2010, 2010. 